\title{
Two Birds, One Stone: Double Hits on Tumor Growth and Lymphangiogenesis by Targeting Vascular Endothelial Growth Factor Receptor 3
}

\author{
Ming-Chuan Hsu ${ }^{1}$, Mei-Ren Pan ${ }^{2} \mathbb{D}$ and Wen-Chun Hung ${ }^{1,3, *}$ \\ 1 National Institute of Cancer Research, National Health Research Institutes, Tainan 704, Taiwan; \\ mchsu@nhri.org.tw \\ 2 Institute of Clinical Medicine, College of Medicine, Kaohsiung Medical University, Kaohsiung 807, Taiwan; \\ mrpan@cc.kmu.edu.tw \\ 3 Institute of Medicine, College of Medicine, Kaohsiung Medical University, Kaohsiung 807, Taiwan \\ * Correspondence: hung1228@ms10.hinet.net; Tel.: +886-6-7000123 (ext. 65147)
}

Received: 26 February 2019; Accepted: 19 March 2019; Published: 21 March 2019

\begin{abstract}
Vascular endothelial growth factor receptor 3 (VEGFR3) has been known for its involvement in tumor-associated lymphangiogenesis and lymphatic metastasis. The VEGFR3 signaling is stimulated by its main cognate ligand, vascular endothelial growth factor C (VEGF-C), which in turn promotes tumor progression. Activation of VEGF-C/VEGFR3 signaling in lymphatic endothelial cells (LECs) was shown to enhance the proliferation of LECs and the formation of lymphatic vessels, leading to increased lymphatic metastasis of tumor cells. In the past decade, the expression and pathological roles of VEGFR3 in tumor cells have been described. Moreover, the VEGF-C/VEGFR3 axis has been implicated in regulating immune tolerance and suppression. Therefore, the inhibition of the VEGF-C/VEGFR3 axis has emerged as an important therapeutic strategy for the treatment of cancer. In this review, we discuss the current findings related to VEGF-C/VEGFR3 signaling in cancer progression and recent advances in the development of therapeutic drugs targeting VEGF-C/VEGFR3.
\end{abstract}

Keywords: VEGF-C; VEGFR3; lymphangiogenesis; lymphatic metastasis

\section{Introduction}

Vascular endothelial growth factor receptor (VEGFR) tyrosine kinases are critical regulators in the development and maintenance of blood and lymphatic vascular systems. In mammals, VEGFRs consist of three membrane proteins referred to as VEGFR1 (FLT1), VEGFR2 (KDR/FLK1), and VEGFR3 (FLT4) [1-4]. The activity of VEGFRs is modulated by five secreted glycoproteins, the vascular endothelial growth factors (VEGFs), which include VEGF-A, VEGF-B, VEGF-C, VEGF-D, and PLGF. The VEGF ligands bind to and activate three different VEGFRs, resulting in the stimulation of angiogenesis and lymphangiogenesis [5-7]. The VEGFR1 gene produces two major proteins, a full-length receptor and a soluble VEGFR1 (sFlt-1). Full-length and soluble VEGFR1 are high-affinity receptors for VEGF-A, VEGF-B, and PLGF, and have been shown to function as negative regulators of VEGFR2 signaling [8-11]. In response to VEGF-A binding, VEGFR1 only exerts low activation of intracellular signaling and serves as a decoy receptor for VEGF-A, preventing its binding to VEGFR2 [12]. Although the kinase activity of VEGFR1 is relatively low compared with that of VEGFR2, the binding of PLGF can induce survival signals in endothelial cells and enhance angiogenesis [13]. In addition, several studies have shown that VEGFR1 signaling is critical for tumor growth, metastasis, activation of monocyte/macrophages, and macrophage migration [14-18]. VEGFR2 is another signaling receptor for VEGF-A and has been shown to play an important role in 
mediating vasculogenesis and angiogenesis [19-21]. VEGFR3 preferentially binds to VEGF-C and VEGF-D, and the ligand binding activates its downstream signaling pathways to regulate lymphatic development and function [22-25] (Figure 1).

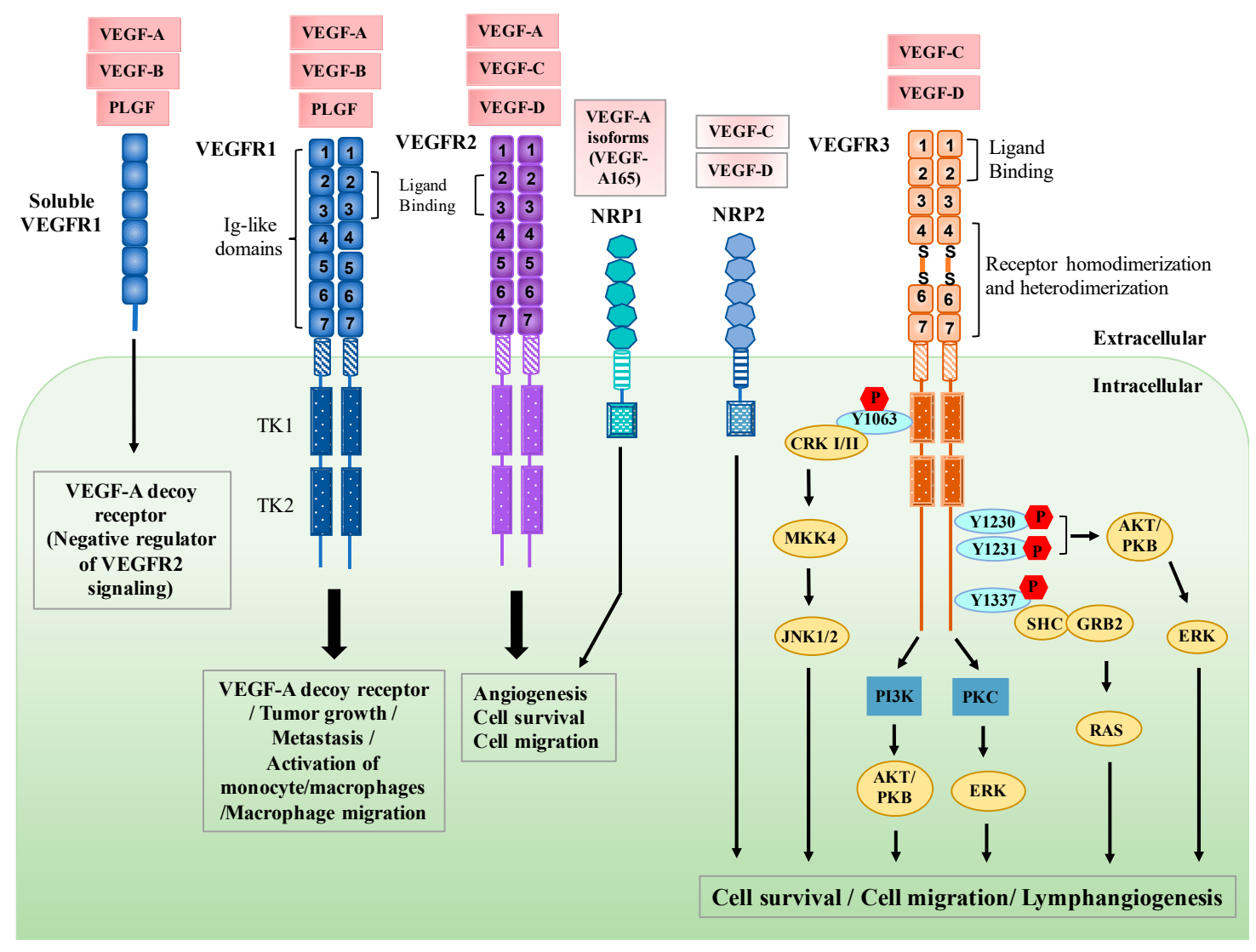

Figure 1. The signaling pathways of vascular endothelial growth factors and vascular endothelial growth factor receptors (VEGFs/VEGFRs) and their biological functions. The three tyrosine kinase (TK) receptors have specific binding capabilities. VEGF-A, VEGF-B, and PLGF can bind to VEGFR1 and mediate its biological functions. The binding of VEGF-A, VEGFR-C, and VEGF-D can stimulate the activation of VEGFR2, resulting in cell proliferation and angiogenesis. VEGF-C and VEGF-D bind to VEGFR3 and induce downstream signaling which mediates cell survival and lymphangiogenesis. Neuropilin 1 (NRP1) and neuropilin 2 (NRP2) can function as co-receptors for VEGFR2 and VEGFR3. The binding of VEGF-A isoforms and NRP1 can form a complex with VEGFR2, leading to the induction of downstream signaling which regulates the proliferation and migration of endothelial cells. VEGF-C/D bind to NRP2 and forms a complex with VEGFR3, activating the VEGFR3 signaling which enhances the proliferation of lymphatic endothelial cells (LECs) and lymphangiogenesis. MKK4, Mitogen-activated protein kinase kinase-4; JNK1/2, c-Jun N-terminal kinase-1/2; PI3K, phosphoinositide-3 kinase; AKT/PKB, AKT/protein kinase B; PKC, protein kinase C; ERK, extracellular signal-related kinase; SHC-GRB2, Src homology domain containing growth factor receptor-bound protein 2.

\section{Regulation of VEGFR3 Signaling}

VEGFRs consist of seven immunoglobulin-like (IG) domains that comprise the ligand-binding part, a single transmembrane domain, and a cytoplasmic tail which contains the split kinase domains for transducing growth factor signals. However, IG domains of VEGFR3 are different from that of other VEGFRs, where the fifth IG domain of VEGFR3 is cleaved and the two processed parts are held together through a disulfide bond [26] (Figure 1). The first and second IG domains of VEGFR3 are responsible for ligand binding, whereas the fourth to seventh IG domains are important for receptor 
homodimerization, heterodimerization (VEGFR2/VEGFR3), and receptor activation [27,28]. It has been known that VEGF-C and VEGF-D have a high affinity for VEGFR3. A previous study shows that VEGF-C is essential for sprouting of the first lymphatic vessels from embryonic veins. In Vegfc-/mice, endothelial cells can commit to the lymphatic endothelial lineage but do not form lymphatic vessel sprouts from the embryonic veins [25]. In contrast, no defects in formation of lymphatic vessel sprouts from the embryonic veins were observed in Vegf-d-deficient mice [29]. However, one study demonstrates that endogenous Vegf-d in mice is dispensable for lymphangiogenesis during development, but its expression significantly contributes to lymphatic metastasis of tumors [30].

VEGF-C binding induces VEGFR3 dimerization and enhances the phosphorylation of tyrosine kinases in the cytoplasmic tail, resulting in the increase of downstream signaling. These phosphotyrosine residues then serve as docking sites for recruiting cytoplasmic signaling mediators that elicit diverse cellular responses such as cell proliferation, migration, and survival. Phosphorylated Tyr1337 has been proposed to be a binding site for the Src homology domain containing growth factor receptor-bound protein 2 (SHC-GRB2) complex, which activates the KRAS signaling pathway and regulates the transformation activity of VEGFR3 [31]. VEGF-C-induced phosphorylation of Tyr1230 and Tyr1231 stimulates the AKT/protein kinase B (AKT/PKB) and extracellular signal-related kinase (ERK) signaling pathways, contributing to proliferation, migration, and survival of lymphatic endothelial cells (LECs) [32,33]. Phosphorylation of Tyr1063 of VEGFR3 mediates cell survival by recruiting CRK $\mathrm{I} / \mathrm{II}$ and inducing c-Jun $\mathrm{N}$-terminal kinase-1/2 (JNK1/2) signaling via mitogen-activated protein kinase kinase-4 (MKK4) [33]. VEGFR3 phosphorylation also triggers phosphoinositide-3 kinase (PI3K)-dependent activation of AKT and protein kinase C (PKC)-dependent activation of ERK1/2 pathways. Stimulation of both signaling pathways promotes the proliferation of lymphatic endothelial cells [32] (Figure 1).

The signaling via VEGFRs is also modulated through interactions with their coreceptors, such as neuropilin 1 (NRP1) and neuropilin 2 (NRP2). Originally, neuropilins were found to be expressed in the nervous and vascular systems and were identified as axonal guidance factors implicated in nerve development. NRP1 is mainly expressed in arteries, whereas NRP2 is expressed in veins and LECs [34,35]. It has been described that NRP1 specifically binds to VEGF-A isoforms such as VEGF-A165 and forms a complex with VEGFR2. The formation of VEGF-A165/NRP1/VEGFR2 complex induces VEGFR2 phosphorylation and downstream signaling, which regulates the proliferation and migration of endothelial cells [36,37]. In the vascular system, the expression of NRP2 and VEGFR3 is mainly in lymphatic vessels [38,39]. Nrp2-deficient mice show small lymphatic vessels and capillaries, which implies that the expression of NRP2 is critical for the development of lymphangiogenesis [38]. Although the mechanism of NRP2-mediated lymphangiogenesis remains unclear, increasing evidence suggests that NRP2 binds to VEGF-C/D and forms a complex with VEGFR3, thereby activating the VEGFR3 signaling which enhances the proliferation of lymphatic endothelial cells and lymphangiogenesis [40-42].

VEGFR3 is initially expressed in all vascular endothelial cells during embryogenesis and early postnatal development but later becomes restricted to LECs and certain fenestrated capillaries $[43,44]$. Since VEGFR3 expression is restricted to lymphatic vessels, it has been used as a marker for lymphatic vessels [45]. However, increasing evidence suggests that VEGFR3 is upregulated in blood vessels in some tumors and chronic wounds during active angiogenesis [46-49]. VEGFR3 has also been shown to be expressed in neuronal progenitors, osteoblasts, and macrophages [50-52]. Furthermore, recent studies have indicated that VEGFR3 expression is detected in different types of cancers and it contributes to tumor progression and lymphatic metastasis (Table 1) [53-93]. 
Table 1. Expression of VEGFR3 in tumor cells.

\begin{tabular}{|c|c|c|c|c|c|}
\hline Tumor Type & Detection & Expression & $\begin{array}{l}\text { Correlate to } \\
\text { Lymph } \\
\text { Angiogenesis }\end{array}$ & $\begin{array}{l}\text { Correlate to } \\
\text { Lymph Node } \\
\text { Metastasis }\end{array}$ & Ref. \\
\hline Urothelial cancer & IHC & Tumor cells & - & - & [53] \\
\hline Breast cancer & IHC, RT-PCR, Western blot & Tumor cells & - & + & [54-56] \\
\hline Lung cancer & IHC, qRT-PCR, Western blot & Tumor cells & - & + & {$[57,58]$} \\
\hline Ovarian cancer & qRT-PCR, IHC, Western blot & Tumor cells & + & + & {$[59,60]$} \\
\hline Renal cell cancer & IHC & Tumor cells & - & + & [61-63] \\
\hline Endometrial cancer & IHC, qRT-PCR, Western blot & Tumor cells & - & + & {$[64,65]$} \\
\hline Colorectal cancer & IHC, qRT-PCR, Western blot & Tumor cells & + & + & [66-68] \\
\hline Gastric cancer & IHC, gRT-PCR & Tumor cells & + & + & {$[69,70]$} \\
\hline Bladder cancer & Western blot & Tumor cells & - & - & [71] \\
\hline Oral cancer & IHC & Tumor cells & + & + & [72] \\
\hline Head and neck cancer & qRT-PCR, qMSP-PCR & Tumor cells & - & - & [73] \\
\hline Esophageal cancer & IHC & Tumor cells & - & - & {$[74,75]$} \\
\hline Cervical cancer & $\begin{array}{l}\text { IHC, in situ hybridization, } \\
\text { qRT-PCR, Western blot }\end{array}$ & Tumor cells & + & + & {$[76,77]$} \\
\hline Prostate cancer & $\begin{array}{c}\text { IHC, in situ hybridization, } \\
\text { qRT-PCR }\end{array}$ & Tumor cells & + & + & {$[78,79]$} \\
\hline Thyroid cancer & IHC & Tumor cells & - & - & {$[80,81]$} \\
\hline Pancreatic cancer & Western blot & Tumor cells & + & + & {$[82,83]$} \\
\hline Neuroblastoma & RT-PCR, Western blot & Tumor cells & - & - & {$[84,85]$} \\
\hline Melanoma & Western blot, IHC & Tumor cells & + & - & {$[86,87]$} \\
\hline Glioblastoma & $\begin{array}{c}\text { In situ hybridization, } \\
\text { qRT-PCR }\end{array}$ & Tumor cells & - & - & {$[88,89]$} \\
\hline Osteosarcoma & IHC & Tumor cells & - & - & [90] \\
\hline Laryngeal cancer & RT-PCR & Tumor cells & + & - & [91] \\
\hline Basal cell carcinoma & qRT-PCR, Western blot & Tumor cells & - & + & [92] \\
\hline Acute myeloid leukemia & RT-PCR, IHC & $\begin{array}{l}\text { Acute myeloid } \\
\text { leukemia } \\
\text { (AML) natural } \\
\text { killer (NK) cells }\end{array}$ & - & - & [93] \\
\hline
\end{tabular}

+ , the expression of VEGFR3 is correlated with angiogenesis or lymph node metastasis; -, the expression of VEGFR3 is not correlated with angiogenesis or lymph node metastasis.

\section{Functional Roles of VEGFR3 in Lymphatic Endothelial Cells}

Lymphatic vessels are an integral part of the cardiovascular system, and are important for tissue fluid homeostasis, immune surveillance, and lipid absorption. The lymphatic vasculature collects extracellular fluids, proteins, lipids, and immune cells through lymphatic capillaries and drains lymph into pre-collector vessels that contain valves, ultimately transporting into the venous circulation $[94,95]$. Defective development of lymphatic vessels causes several disorders including vascular malformation, lymphoedema, and lymphangiectasia [96], whereas enhanced lymphangiogenesis is associated with tumor metastasis and tissue inflammation [97]. It has been shown that growth of lymphatic vessels occurs upon the exposure of LECs to VEGF-C-induced VEGFR3 signaling [25]. Available data support that VEGFR3 is critical for lymphatic vessel development. For example, VEGFR3 mutations identified in human and mice are known to cause lymphoedema [24,98,99]. Moreover, mice with Vegfr3 deletion die at around E10.5 due to failure of cardiovascular development [100]. Furthermore, VEGF-C/VEGFR3 signaling is also implicated in modulating the remodeling and homeostasis of lymphatic vessels. A study of Vegf-c-deficient mice suggested that VEGF-C signaling was required for the migration of LECs and the formation of lymphatic vessel sprouts from embryonic veins [25]. A recent study shows that LECs of Vegf-c-deficient mouse embryos fail to detach from the cardinal vein and are unable to form the dorsal peripheral longitudinal lymphatic vessel (PLLV) and the ventral primordial thoracic duct (pTD), which results in lethality of mouse embryos [101]. Results obtained from genetically engineered animals further support the essential role of VEGF-C in lymphangiogenesis showing that depletion of the matrix-binding adapter protein CCBE1 reduces proteolytic processing of VEGF-C by protease A disintegrin and ADAMTS3 metalloprotease, resulting in the attenuation of the VEGFR3 signaling and lymphangiogenesis [102,103]. In addition, overexpression of VEGF-C induces the proliferation of LECs and hyperplasia of the lymphatic vasculature through VEGFR3 [104]. 


\section{Clinical Significance of VEGF-C/VEGFR3 Expression in Tumors}

Lymphangiogenesis is an important step in tumor progression. Dysregulation of lymphangiogenic factors has been known to promote lymphangiogenesis, which induces the formation of new lymphatic vessels that connect with the surrounding lymphatic vessels and provide routes for the transport of tumor cells to distant sites. The potential roles of the VEGFR-C/VEGFR3 axis in regulating tumor lymphangiogenesis and progression have been suggested. The expression of VEGF-C is detected in a variety of human tumors [105-112] and the increased level of VEGF-C is significantly correlated with lymph node metastasis, distant metastasis, and poor prognosis [97,113]. VEGF-C overexpression in breast cancer cells activates the VEGF-C/VEGFR3 axis in LECs and induces the formation of lymphatic vessels within and around tumors, resulting in enhanced tumor metastasis through lymphatic vessels [114,115] (Figure 2). In addition, mice bearing VEGF-C-overexpressing human breast carcinoma cells exhibited increased lymphangiogenesis and tumor metastasis via the lymphatic vessels [116]. Moreover, a soluble form of VEGFR-3, a potent inhibitor of VEGF-C/VEGF-D signaling, can inhibit lymphangiogenesis and suppress tumor metastasis [117].

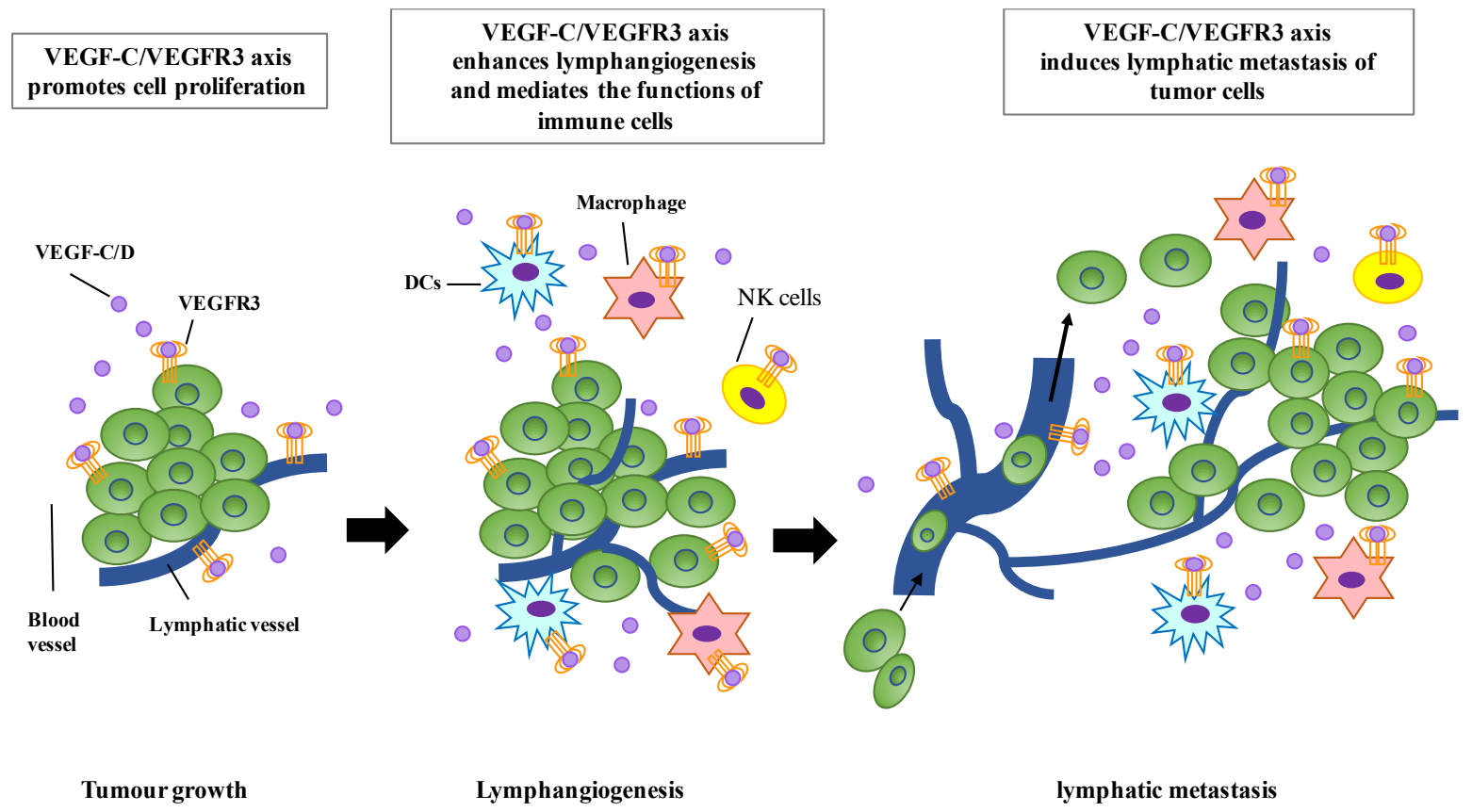

Figure 2. The function roles of VEGF-C/VEGFR3 signaling in tumor progression. The VEGF-C/VEGFR3 axis promotes tumor growth in autocrine and paracrine manners. VEGF-C can enhance the proliferation of LECs through VEGFR3, resulting in lymphangiogenesis and lymphatic metastasis of tumor cells. VEGF-C/VEGFR3 signaling can also mediate the functions of immune cells, including dendritic cells (DCs), macrophages, and natural killer (NK) cells.

VEGFR3 is primarily expressed in LECs, but is also expressed in non-endothelial cells, such as tumor cells (Table 1). Recently, Batsi et al. reported that the expression of VEGFR3 was detected in the nuclei of tumor cells and endothelial cells of tumor vessels in both primary urothelial bladder carcinoma and their recurrent tumors. However, the expression of VEGFR3 was not correlated with tumor grade and clinical stage [53]. Previous studies have also demonstrated that VEGFR3 protein was detected in breast cancer specimens. High expression levels of several angiogenesis-related proteins, including VEGFR3, are observed in patients with early-stage breast cancer and are associated with clinicopathological parameters and survival outcome [54]. It has been shown in a mouse model that the expression of VEGF-C and VEGFR3 promotes tumor growth and metastasis in an autocrine manner, whereas treatment with a VEGFR3 antagonist significantly suppresses tumor growth and 
lung metastasis [55]. Eroglu et al. also found that, while VEGFR3 is expressed in breast cancer cells, its expression is not associated with lymph node metastasis [56].

A recent study demonstrated that tumor-associated macrophages induced the expression of VEGF-C and VEGFR3 in lung adenocarcinoma cells, resulting in enhanced migration and invasion of cancer cells. Blockade of VEGFR3 signaling inhibits tumor growth and markedly suppresses the migration and invasion of tumor cells by upregulating the expression of p53 and PTEN. Furthermore, the study's data revealed that the inhibition of VEGFR3 enhances chemosensitivity of doxorubicin in lung adenocarcinoma cells [58].

VEGFR3 expression has also been found in ovarian cancer cells and activation of the VEGFR3 signaling is induced by VEGF-C, which is produced by tumor-associated myeloid cells. The inhibition of VEGFR3 signaling results in the down-regulation of BRCA expression and cell cycle arrest. Moreover, VEGFR3 blockade chemosensitizes ovarian cancer to cisplatin chemotherapy in vitro and in vivo [59]. Decio et al. confirmed that VEGF-C and VEGFR3 were expressed in ovarian tumor tissues. VEGF-C released by tumor cells stimulates the VEGFR3 signaling in a paracrine and autocrine manner, leading to an increase in tumor growth and metastasis. Targeting the VEGF-C/VEGFR3 pathway decreases tumor burden and dissemination of ovarian tumors [60]. In renal cell cancer (RCC), the expression of VEGFR3 has been demonstrated in several studies [61,62]. Furthermore, Zhang et al. showed that VEGFR3 expression is correlated with histological grade, the status of lymph node, and metastasis in papillary renal cell carcinoma. Moreover, the expression of VEGFR3 can serve as a prognostic marker for papillary renal cell carcinoma and is also a predictor of lymph node metastasis as well [63].

Immunohistochemical analysis and qRT-PCR studies have demonstrated that the expression of VEGFR3 was increased in endometrial carcinomas compared with normal endometrium $[64,65]$. Additionally, VEGFR3 expression was significantly associated with tumor stage and poor disease-free survival in endometrial carcinomas [64]. Zhu et al. found that VEGFR3 was highly expressed in tissue samples of colorectal cancer. High expression of VEGFR3 was associated with the TNM (tumor, node, metastasis) stage and lymph node metastasis of colorectal cancer. The authors further illustrated that lipopolysaccharide (LPS) could upregulate VEGFR3 expression through increasing the binding of NF- $\mathrm{KB}$ to the promoter of VEGFR3, thereby promoting the migration and invasion of colorectal cancer cells [66]. Another study also showed that VEGFR3 expression was found in colorectal cancer and its expression was associated with lung metastasis [67].

A previous study showed that VEGFR3 expression was also found in gastric cancer and correlated with poorer prognosis, TNM stage, and lymphatic metastasis [69]. Recently, Dai et al. showed in an orthotopic mouse model that treatment with VEGFR3 antibody-conjugated ginsenoside Rg3 nano-emulsion might inhibit the expression of VEGF-C, VEGF-D, and VEGFR3, resulting in the suppression of tumor growth and lymphatic metastasis of human gastric cancer [70]. The expression of VEGFR3 mRNA and protein were also detected in multiple cancers, including bladder, oral, head and neck, esophageal, and cervical cancers [71-77].

In prostate cancer, Yang et al. demonstrated that VEGF-C mRNA and VEGFR3 were highly expressed in tumorous prostate tissue. The expression of VEGFR3 is higher in VEGF-C mRNA-positive tumors compared to VEGF-C mRNA-negative tumor tissues. Thus, VEGFR3 expression is associated with poor prognosis and metastasis in human prostate cancer [79]. High expression levels of VEGFR2 and VEGFR3 were also detected in several medullary thyroid carcinoma (MTC) samples [80]. Another study investigated the influence of RAS mutation on the expression of TKI target proteins in MTC tumors. The results showed that VEGFR3 protein is expressed in few RAS-positive tumors and VEGF is frequently expressed in wild-type tumors. These findings could improve the selection of MTC patients for targeted therapy [81]. Kurenova et al. demonstrated that focal adhesion kinase (FAK) and VEGFR3 form a complex to promote cell proliferation in pancreatic ductal adenocarcinoma (PDA). They further showed that a small molecule inhibitor $C 4$ could disrupt the interaction of FAK and VEGFR3 and inactivate FAK/VEGFR3 signaling to suppress cancer cell growth. Moreover, the combination of C4 and gemcitabine showed a significant synergistic effect on tumor suppression in PDA [82]. Another 
small molecule inhibitor C10 was also found to target the FAK/VEGFR3 complex and inhibit the growth of pancreatic tumor in vivo [83].

The expression of VEGFR3 has been detected in neuroblastoma cell lines, and the blockade of FAK-VEGFR3 interaction by $\mathrm{C} 4$ has also reduced cellular migration and proliferation. In addition, the combination of $C 4$ and doxorubicin significantly suppressed tumor growth in a xenograft animal model $[84,85]$. VEGFR3 expression has been found in melanoma. Targeting FAK-VEGFR3 interaction by the small molecule C4 significantly inhibits melanoma tumor growth in vivo [87]. Recently, VEGF-C and VEGFR3 were found to be expressed in basal cell carcinoma (BCC). Yeh et al. demonstrated that the VEGF-C/VEGFR3 axis enhances the migration, invasion, and stemness of skin cancer cells via the KRAS/YAP1/Slug pathway. Targeting the VEGF-C/VEGFR3 axis by VEGFR3 blocking peptide significantly suppressed skin cancer progression [92].

\section{Expression and Function of VEGFR3 in Immune Cells}

Lymphatic vessels transport fluid, soluble antigens, and immune cells from peripheral tissues to draining lymph nodes (dLNs), where adaptive immunity and tolerance are modulated $[118,119]$. In addition to providing the routes for the trafficking of peripherally activated dendritic cells (DCs) into dLNs to activate immune response, lymphatic vessels also provide the routes for cellular egress leading to immune resolution $[120,121]$. It has been reported that lymphangiogenesis often occurs in chronic inflammatory tissues, including inflammatory bowel disease, chronic airway inflammation, and psoriasis $[120,122,123]$. VEGF-C and VEGFR3 are largely responsible for the development of lymphatic vessels. The pathogenic roles of VEGF-C and VEGFR3 in chronic inflammatory diseases and immune response have been well characterized in recent investigations. A previous study showed that the systemic inhibition of VEGFR3 increases the formation of inflammatory edema and inflammatory cell accumulation despite the inhibition of lymphangiogenesis in a Keratin 14 (K14)-VEGF-A transgenic (Tg) mouse model. Chronic delivery of VEGF-C or VEGF-D (which activates VEGFR3 signaling) into the skin of K14-VEGF-A mice significantly suppressed chronic skin inflammation, epidermal hyperplasia, and accumulation of CD8 cells. Similar results were also found by intracutaneous injection of recombinant VEGF-C156S mutant protein, a specific VEGFR3 ligand, which significantly reduced skin inflammation [121]. D'Alessio et al. demonstrated that increased lymphangiogenesis and lymphatic function reduced inflammatory bowel disease. The authors found that the VEGF-C/VEGFR3 signaling mediates "resolving" macrophage activation and mobilization in a STAT6-dependent manner, resulting in bacterial antigen clearance from the inflammatory area to the draining lymph nodes [120]. Furthermore, the expression of VEGFR3 in different immune cells has been reported. Hamrah et al. demonstrated the expression of VEGFR3 in corneal DCs and its up-regulation in inflammation. The authors further characterized that VEGFR3 ${ }^{+} \mathrm{DC}$ s are $\mathrm{CD} 11 \mathrm{c}^{+} \mathrm{CD} 45^{+} \mathrm{CD} 11 \mathrm{~b}^{+}$and mostly major histocompatibility (MHC) class $\mathrm{II}^{-} \mathrm{CD} 80^{-} \mathrm{CD} 86^{-}$, which belong to immature DCs of the monocytic lineage [124]. In addition, Fernandez Pujol et al. reported that VEGFR3 is detected in immature DCs. In the presence of angiogenic growth factors, the immature DCs can differentiate into endothelial-like cells [125]. The expression of VEGF-C, VEGF-D, and VEGFR3 in tumor-associated macrophages (TAMs) has been shown in human cervical cancer [126]. The study indicates that VEGF-C/VEGFR3-expressing TAMs may play an important role in peritumoral lymphangiogenesis. Moreover, Su et al. also demonstrate that the VEGF-C/VEGFR3 axis is critical for macrophage infiltration in lung cancer, and VEGFR3-mediated macrophage infiltration may be involved in the radiosensitization of lung cancer [127]. More recently, Zhang et al. show that Gram-negative bacterial infection or LPS stimulation can elevate the expression of VEGFR3 and VEGF-C through TLR4-NF-kB signaling in macrophage, whereas VEGF-C ligation of VEGFR3 forms a negative feedback loop to inhibit TLR4-induced inflammatory responses. Their results represent a self-control mechanism to prevent uncontrolled inflammation in macrophages during bacterial infection [128]. The expression of VEGFR3 was also reported in natural killer (NK) cells. Lee et al. showed that the NK cells from acute myeloid leukemia (AML) express higher levels of VEGFR3 and lower levels of IFN- $\gamma$ compared to 
the NK cells from healthy donors [93]. Moreover, increased lymphatic vessels and lymph drainage are correlated with tumor progression and tumor-associated lymphangiogenesis to enhance immune tolerance [129-131]. Emerging evidence also demonstrates that inflammatory lymphangiogenesis is correlated with graft rejection in renal and renal transplants [132,133]. Therefore, it is likely that VEGFR3 in immune cells might play complex roles in stimulation and resolution of immune response.

\section{Development of Drugs That Target VEGF-C/VEGFR3 Signaling}

As mentioned previously, tumor-associated lymphangiogenesis plays a critical role in the mediation of tumor metastasis and has emerged as a novel target for cancer treatment $[134,135]$. Currently, multiple therapeutic strategies have been developed for targeting VEGF-C/VEGFR3 signaling, including (1) small molecule receptor tyrosine kinase inhibitors (TKIs) of VEGFR3; (2) monoclonal antibodies or receptor traps targeting VEGF-C; and (3) neutralizing antibodies or peptides that block the VEGFR3 signaling.

\subsection{Small Molecule TKIs of VEGFR3}

Several TKIs have been developed for inhibiting the kinase activity of VEGFRs. Four TKIs that can be administered orally, namely, sorafenib, sunitinib, pazopanib, and axitinib, have been approved by the US Food and Drug Administration (FDA) and the European Medicines Agency (EMA) for clinical use [136,137] (Figure 3). The therapeutic efficacy of sorafenib monotherapy has been shown in patients with advanced renal cell carcinoma (RCC) and hepatocellular carcinoma (HCC) $[138,139]$. Sunitinib monotherapy has also shown significant improvement in progression-free survival (PFS) in patients with metastatic RCC [140]. The activity of pazopanib monotherapy was assessed in locally advanced or metastatic RCC, which showed improvement in PFS [141]. Recently, the therapeutic efficacy of axitinib has been demonstrated in metastatic renal cell carcinoma (mRCC) and the promising therapeutic efficacy of axitinib was demonstrated. Therefore, axitinib has been approved by the US FDA and EMA in the treatment of mRCC [137].

Cediranib is an oral VEGFR TKI and has been shown to suppress the activity of VEGFR2 and VEGFR3, leading to the inhibition of angiogenesis and lymphangiogenesis [142]. In the phase III ICON 6 trial, cediranib monotherapy has shown promising efficacy in platinum-sensitive relapsed ovarian cancer [143]. Brivanib, a selective dual inhibitor of VEGFRs and fibroblast growth factor receptors (FGFRs), has been evaluated in patients with advanced HCC. However, the results from phase III trials suggest that brivanib as an adjuvant therapy to transarterial chemoembolization (TACE) did not improve overall survival [144]. Moreover, the efficacy and safety of vandetanib in patients with advanced RET-rearranged non-small-cell lung cancer (NSCLC) was assessed in phase II trials. The clinical anti-tumor activity and a manageable safety profile of vandetanib were observed in patients with advanced RET-rearranged NSCLC $[145,146]$. Another TKI, motesanib, was tested in phase III trials in combination with paclitaxel and carboplatin $(\mathrm{P} / \mathrm{C})$ in advanced NSCLC patients. However, motesanib plus P/C did not significantly improve PFS [147] (Figure 3). Although the anti-tumor activity of TKIs has been reported, they are not highly selective since most of them target the ATP binding pocket. For example, sorafenib and sunitinib have been demonstrated to inhibit VEGFRs, platelet-derived growth factor receptors (PDGFRs), FGFRs, KIT, RET, and FLT3. These multi-targeted TKIs block a variety of kinases in addition to VEGFRs, resulting in adverse effects unrelated to VEGFR blockade. Therefore, the development of more specific VEGFR TKIs will improve anti-lymphangiogenic and anti-tumor activity with fewer off-target effects. Very recently, a small molecule TKI, SAR131675, has been reported to be highly specific for VEGFR3. The treatment of SAR131675 suppresses lymphangiogenesis and lymphatic metastasis in several experimental tumor models [148,149] (Figure 3). 


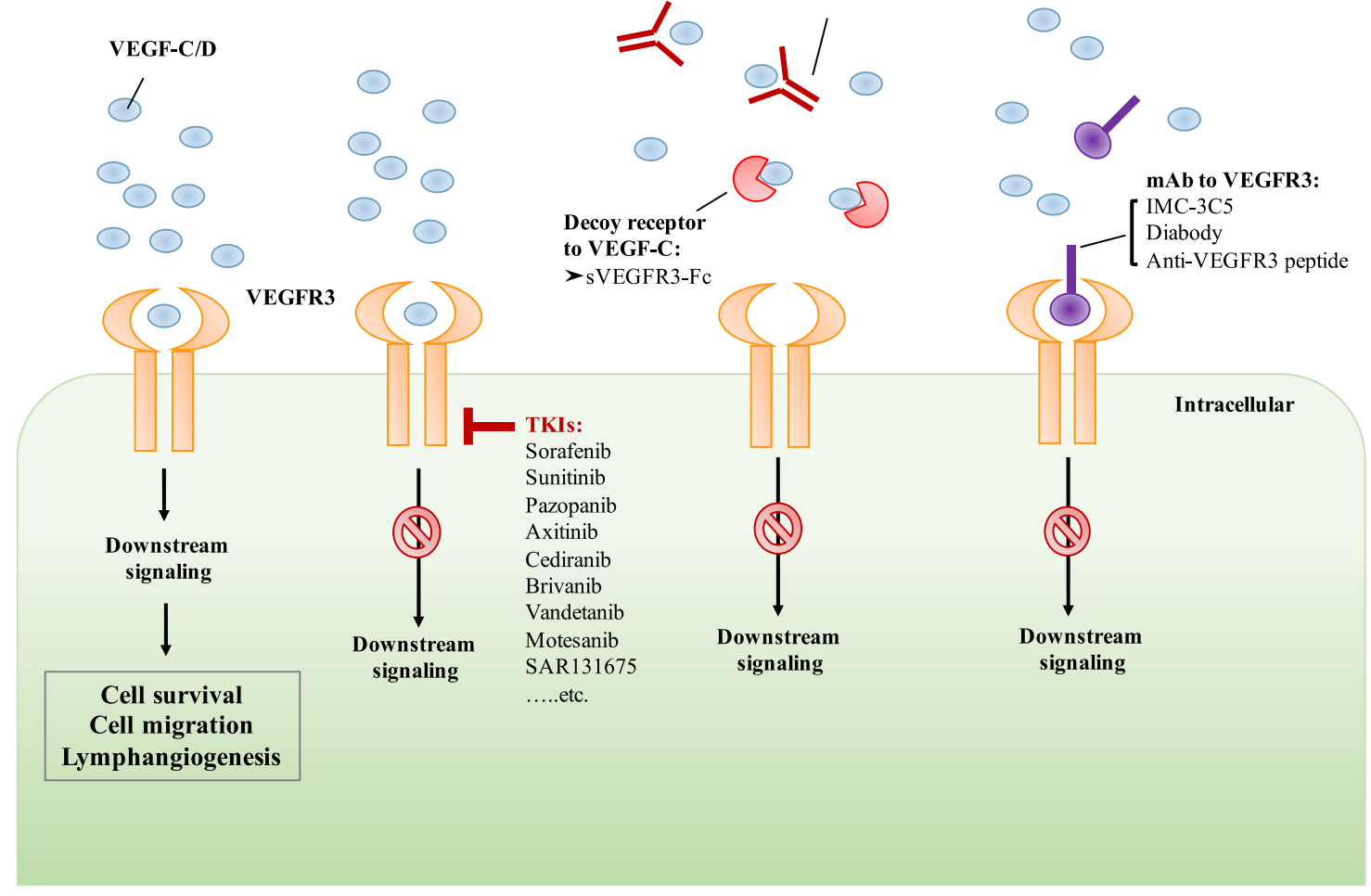

Figure 3. Targeting the VEGF-C/VEGFR3 axis by various therapeutic strategies. The binding of VEGF-C/D to VEGFR3 induces downstream signaling which mediates cell survival and lymphangiogenesis. The treatment of small molecule receptor tyrosine kinase inhibitors (TKIs) inhibits the activation of VEGF-C/D/VEGFR3 signaling. Monoclonal antibody (mAb) and receptor trap target VEGF-C, preventing its binding to VEGFR3. Monoclonal antibody or peptides targeting VEGFR3 prevent the binding of VEGF-C, resulting in the inhibition of VEGFR3 signaling.

\subsection{Monoclonal Antibody Targeting VEGF-C/VEGFR3}

Targeting the VEGF/VEGFRs signaling axis by using monoclonal antibodies has been demonstrated in recent years. The humanized anti-VEGF monoclonal antibody, bevacizumab, is an antibody approved by the US FDA for clinical use [150-152]. Bevacizumab-induced VEGF-A neutralization can prevent the binding of VEGF-A to VEGFR1 and VEGFR2, suppressing their activation and subsequent signaling cascades. Another neutralizing antibody against VEGFR2, ramucirumab, has also been approved for the treatment of various cancers including advanced gastric or gastro-esophageal junction adenocarcinoma, NSCLC, and advanced or metastatic urothelial carcinoma. Recently, a specific anti-VEGFR3 monoclonal antibody, IMC-3C5, has been assessed and has completed phase I trials in patients with advanced solid tumors and colorectal cancer (CRC). The results from the phase I study indicated that IMC-3C5 was well-tolerated up to the highest planned dose, but anti-tumor activity was not significant in CRC [153]. Another drug targeting the VEGF-C/VEGFR3 axis is VGX-100, a fully humanized VEGF-C neutralizing antibody which specifically binds to VEGF-C protein and thereby prevents its binding to VEGFR3. The therapeutic activity of VGX-100 was assessed in patients with advanced solid tumors in clinical phase I, and the trial was recently completed (ClinicalTrials.gov Identifier: NCT01514123) [154] (Figure 3). However, the results have not yet been published.

Numerous antibodies, soluble receptor proteins, and IgG fusion proteins targeting the VEGF-C/VEGFR3 axis have been investigated in preclinical studies. Jimenez et al. developed a bispecific antibody which binds to both VEGFR2 and VEGFR3 in a dose-dependent manner and inhibits 
the interaction of VEGF-A/VEGFR2 and VEGF-C/VEGFR3. Their results showed a simultaneous dual blockade of VEGFR2 and VEGFR3 by the antibody, subsequently inhibiting the migration of endothelial cells [155]. A previous study demonstrated that a soluble VEGFR3 decoy receptor, sVEGFR3-Fc, expressed by a recombinant adeno-associated viral vector, potently suppressed tumor-associated lymphangiogenesis and lymphatic metastasis in highly metastatic melanoma, renal cell carcinoma, and prostate cancer models [156]. By using antibody phage-display, Rinderknecht et al. developed a human monoclonal antibody fragment (single-chain fragment variable, scFv) that specifically binds to VEGF-C with high affinity and inhibits VEGF-C/VEGFR3 signaling [157]. A new receptor-immunoglobulin (Ig) fusion protein, VEGFR3-Ig, that could simultaneously bind to VEGF-A and VEGF-C has been reported recently. VEGFR3-Ig has been shown to block tumor-associated angiogenesis, lymphangiogenesis, and metastasis in a highly metastatic HCC model [158]. In addition, Yeh et al. showed that VEGF-C/VEGFR3-mediated KRAS/YAP1/Slug pathway could be suppressed by treatment with anti-VEGFR3 peptide, leading to the inhibition of migration, invasion, and stemness of skin cancer cells [92] (Figure 3).

\section{Conclusions}

The VEGF-C/VEGFR3 axis has been implicated in cancer progression by directly affecting tumor cells or modulating lymphangiogenesis and immune response. High expression of VEGF-C/VEGFR3 has been demonstrated to be correlated with increased lymphatic metastasis and poor prognosis in numerous types of cancers (Table 1). Over the last two decades, tumor-associated lymphangiogenesis is considered as a potential target for treating metastatic diseases. Therefore, the development of drugs targeting the VEGF-C/VEGFR3 signaling has received much attention, which could be beneficial for patients with VEGF-C/VEGFR3-driven cancers. Multiple VEGFR TKIs have been tested in clinical/preclinical studies, and several VEGFR TKIs have been approved for clinical use (Table 2). However, these agents might inhibit multiple kinases in addition to VEGFR3, and the "off-target" effects might increase adverse effects. Hence, development of more selective and specific anti-VEGFR3 TKIs is required. In addition, the VEGF-C/VEGFR3 signaling has been shown to be involved in regulating immune tolerance and suppression $[93,120,121]$. Targeting the VEGF-C/VEGFR3 axis could enhance anti-tumor immune responses. Currently, several studies focused on VEGF-C/VEGFR3-mediated immunobiology in LECs and immune cells are now growing. The results from these studies will increase our understanding of how the VEGF-C/VEGFR3 axis affects immunity and will provide the rationale for the development of new immunotherapeutic strategies for cancer therapy.

Table 2. Therapeutic agents for the inhibition of VEGF-C/VEGFR3 signaling.

\begin{tabular}{|c|c|c|c|c|}
\hline Agents & Agent Description & Developer & Current Status & Ref. \\
\hline Sorafenib & $\begin{array}{c}\text { Small molecule TKI } \\
\text { (VEGFRs, PDGFRs, } \\
\text { c-kit, RET) }\end{array}$ & Bayer and Onyx & FDA-approved & [138] \\
\hline Sunitinib & $\begin{array}{c}\text { Small molecule TKI } \\
\text { (VEGFRs, PDGFRs, } \\
\text { c-kit, Flt3, RET) }\end{array}$ & Pfizer Inc. & FDA-approved & [140] \\
\hline Pazopanib & $\begin{array}{c}\text { Small molecule TKI } \\
\text { (VEGFRs, PDGFRs, } \\
\text { c-kit) }\end{array}$ & GlaxoSmithKline & FDA-approved & [141] \\
\hline Axitinib & $\begin{array}{c}\text { Small molecule TKI } \\
\text { (VEGFRs, PDGFRs, } \\
\text { c-kit) }\end{array}$ & Pfizer Inc. & FDA-approved & {$[142,143]$} \\
\hline Cediranib & $\begin{array}{c}\text { Small molecule TKI } \\
\text { (VEGFRs, PDGFRs, } \\
\text { c-kit) }\end{array}$ & AstraZeneca & Phase III & [137] \\
\hline
\end{tabular}


Table 2. Cont.

\begin{tabular}{|c|c|c|c|c|}
\hline Agents & Agent Description & Developer & Current Status & Ref. \\
\hline Brivanib & $\begin{array}{c}\text { Small molecule TKI } \\
\text { (VEGFRs, PDGFRs, } \\
\text { FGFRs) }\end{array}$ & $\begin{array}{l}\text { Bristol-Myers } \\
\text { Squibb }\end{array}$ & Phase III & [144] \\
\hline Vandetanib & $\begin{array}{c}\text { Small molecule TKI } \\
\text { (VEGFRs, PDGFRs, } \\
\text { EGFR, RET) }\end{array}$ & AstraZeneca & Phase II & {$[145,146]$} \\
\hline Motesanib & $\begin{array}{l}\text { Small molecule TKI } \\
\text { (VEGFRs, PDGFRs, } \\
\text { c-kit, RET) }\end{array}$ & Amgen & Phase III & [147] \\
\hline SAR131675 & $\begin{array}{c}\text { Small molecule TKI } \\
\text { (more selective for } \\
\text { VEGFR3 than VEGFR1/2) }\end{array}$ & Sanofi & Preclinical & {$[148,149]$} \\
\hline Bevacizumab & $\begin{array}{c}\text { Humanized } \\
\text { anti-VEGF-A mAb }\end{array}$ & Genentech & FDA-approved & [150] \\
\hline IMC-3C5 & $\begin{array}{c}\text { Humanized } \\
\text { anti-VEGFR3 mAb }\end{array}$ & $\begin{array}{c}\text { ImClone } \\
\text { Systems/Eli Lilly }\end{array}$ & Phase I & [153] \\
\hline VGX-100 & $\begin{array}{c}\text { Humanized } \\
\text { anti-VEGF-C mAb }\end{array}$ & $\begin{array}{c}\text { Circadian } \\
\text { Technologies }\end{array}$ & Phase I & [154] \\
\hline Diabody & $\begin{array}{l}\text { Anti-VEGFR2/ } \\
\text { VEGFR3 mAb }\end{array}$ & - & Preclinical & [155] \\
\hline sVEGFR3-Fc & $\begin{array}{l}\text { Soluble VEGFR3 decoy } \\
\text { receptor }\end{array}$ & - & Preclinical & [156] \\
\hline $\begin{array}{l}\text { Single-chain } \\
\text { fragment }(\mathrm{scFv})\end{array}$ & $\begin{array}{c}\text { Anti-VEGF-C } \\
\text { mAb fragment } \\
\text { Anti-VEGF-C/A }\end{array}$ & - & Preclinical & [157] \\
\hline VEGFR3-Ig & $\begin{array}{l}\text { Receptor-Ig } \\
\text { fusion protein }\end{array}$ & - & Preclinical & [158] \\
\hline $\begin{array}{l}\text { Anti-VEGFR3 } \\
\text { peptide }\end{array}$ & Anti-VEGFR3 peptide & - & Preclinical & [92] \\
\hline
\end{tabular}

Author Contributions: M.-C.H. designed the review structure and the figures and wrote the manuscript. M.-R.P. and W.-C.H. contributed to the conceptual clarity and critical editing of the manuscript. All authors read and approved the manuscript.

Funding: This work was supported by the following grants: MOST 103-2320-B-400-014, 104-2320-B-400-010-MY3, and 107-2320-B-400-012 from the Ministry of Science and Technology.

Conflicts of Interest: The authors declare no conflicts of interest.

\section{References}

1. Shibuya, M.; Yamaguchi, S.; Yamane, A.; Ikeda, T.; Tojo, A.; Matsushime, H.; Sato, M. Nucleotide sequence and expression of a novel human receptor-type tyrosine kinase gene (flt) closely related to the fms family. Oncogene 1990, 5, 519-524.

2. Matthews, W.; Jordan, C.T.; Gavin, M.; Jenkins, N.A.; Copeland, N.G.; Lemischka, I.R. A receptor tyrosine kinase cdna isolated from a population of enriched primitive hematopoietic cells and exhibiting close genetic linkage to c-kit. Proc. Natl. Acad. Sci. USA 1991, 88, 9026-9030. [CrossRef] [PubMed]

3. Pajusola, K.; Aprelikova, O.; Korhonen, J.; Kaipainen, A.; Pertovaara, L.; Alitalo, R.; Alitalo, K. Flt4 receptor tyrosine kinase contains seven immunoglobulin-like loops and is expressed in multiple human tissues and cell lines. Cancer Res. 1992, 52, 5738-5743. [PubMed]

4. Aprelikova, O.; Pajusola, K.; Partanen, J.; Armstrong, E.; Alitalo, R.; Bailey, S.K.; McMahon, J.; Wasmuth, J.; Huebner, K.; Alitalo, K. Flt4, a novel class iii receptor tyrosine kinase in chromosome 5q33-qter. Cancer Res. 1992, 52, 746-748. [PubMed]

5. Matthews, W.; Jordan, C.T.; Wiegand, G.W.; Pardoll, D.; Lemischka, I.R. A receptor tyrosine kinase specific to hematopoietic stem and progenitor cell-enriched populations. Cell 1991, 65, 1143-1152. [CrossRef]

6. Shibuya, M.; Claesson-Welsh, L. Signal transduction by vegf receptors in regulation of angiogenesis and lymphangiogenesis. Exp. Cell Res. 2006, 312, 549-560. [CrossRef] 
7. Terman, B.I.; Carrion, M.E.; Kovacs, E.; Rasmussen, B.A.; Eddy, R.L.; Shows, T.B. Identification of a new endothelial cell growth factor receptor tyrosine kinase. Oncogene 1991, 6, 1677-1683.

8. Olofsson, B.; Korpelainen, E.; Pepper, M.S.; Mandriota, S.J.; Aase, K.; Kumar, V.; Gunji, Y.; Jeltsch, M.M.; Shibuya, M.; Alitalo, K.; et al. Vascular endothelial growth factor b (vegf-b) binds to vegf receptor-1 and regulates plasminogen activator activity in endothelial cells. Proc. Natl. Acad. Sci. USA 1998, 95, 11709-11714. [CrossRef]

9. Park, J.E.; Chen, H.H.; Winer, J.; Houck, K.A.; Ferrara, N. Placenta growth factor. Potentiation of vascular endothelial growth factor bioactivity, in vitro and in vivo, and high affinity binding to flt-1 but not to flk-1/kdr. J. Biol. Chem. 1994, 269, 25646-25654.

10. Sawano, A.; Takahashi, T.; Yamaguchi, S.; Aonuma, M.; Shibuya, M. Flt-1 but not kdr/flk-1 tyrosine kinase is a receptor for placenta growth factor, which is related to vascular endothelial growth factor. Cell Growth Differ. 1996, 7, 213-221.

11. Kendall, R.L.; Thomas, K.A. Inhibition of vascular endothelial cell growth factor activity by an endogenously encoded soluble receptor. Proc. Natl. Acad. Sci. USA 1993, 90, 10705-10709. [CrossRef] [PubMed]

12. Waltenberger, J.; Claesson-Welsh, L.; Siegbahn, A.; Shibuya, M.; Heldin, C.H. Different signal transduction properties of kdr and flt1, two receptors for vascular endothelial growth factor. J. Biol. Chem. 1994, 269, 26988-26995.

13. Luttun, A.; Tjwa, M.; Moons, L.; Wu, Y.; Angelillo-Scherrer, A.; Liao, F.; Nagy, J.A.; Hooper, A.; Priller, J.; De Klerck, B.; et al. Revascularization of ischemic tissues by plgf treatment, and inhibition of tumor angiogenesis, arthritis and atherosclerosis by anti-flt1. Nat. Med. 2002, 8, 831-840. [CrossRef] [PubMed]

14. Hiratsuka, S.; Nakamura, K.; Iwai, S.; Murakami, M.; Itoh, T.; Kijima, H.; Shipley, J.M.; Senior, R.M.; Shibuya, M. Mmp9 induction by vascular endothelial growth factor receptor-1 is involved in lung-specific metastasis. Cancer Cell 2002, 2, 289-300. [CrossRef]

15. Kaplan, R.N.; Riba, R.D.; Zacharoulis, S.; Bramley, A.H.; Vincent, L.; Costa, C.; MacDonald, D.D.; Jin, D.K.; Shido, K.; Kerns, S.A.; et al. Vegfr1-positive haematopoietic bone marrow progenitors initiate the pre-metastatic niche. Nature 2005, 438, 820-827. [CrossRef] [PubMed]

16. Murakami, M.; Iwai, S.; Hiratsuka, S.; Yamauchi, M.; Nakamura, K.; Iwakura, Y.; Shibuya, M. Signaling of vascular endothelial growth factor receptor-1 tyrosine kinase promotes rheumatoid arthritis through activation of monocytes/macrophages. Blood 2006, 108, 1849-1856. [CrossRef]

17. Muramatsu, M.; Yamamoto, S.; Osawa, T.; Shibuya, M. Vascular endothelial growth factor receptor-1 signaling promotes mobilization of macrophage lineage cells from bone marrow and stimulates solid tumor growth. Cancer Res. 2010, 70, 8211-8221. [CrossRef] [PubMed]

18. Niida, S.; Kondo, T.; Hiratsuka, S.; Hayashi, S.; Amizuka, N.; Noda, T.; Ikeda, K.; Shibuya, M. Vegf receptor 1 signaling is essential for osteoclast development and bone marrow formation in colony-stimulating factor 1-deficient mice. Proc. Natl. Acad. Sci. USA 2005, 102, 14016-14021. [CrossRef]

19. Olsson, A.K.; Dimberg, A.; Kreuger, J.; Claesson-Welsh, L. Vegf receptor signalling-In control of vascular function. Nat. Rev. Mol. Cell Biol. 2006, 7, 359-371. [CrossRef]

20. Koch, S.; Claesson-Welsh, L. Signal transduction by vascular endothelial growth factor receptors. Cold Spring Harb. Perspect. Med. 2012, 2, a006502. [CrossRef]

21. Zonta, Y.R.; Martinez, M.; Camargo, I.C.; Domeniconi, R.F.; Lupi Junior, L.A.; Pinheiro, P.F.; Reiter, R.J.; Martinez, F.E.; Chuffa, L.G. Melatonin reduces angiogenesis in serous papillary ovarian carcinoma of ethanol-preferring rats. Int. J. Mol. Sci. 2017, 18, 763. [CrossRef]

22. Joukov, V.; Pajusola, K.; Kaipainen, A.; Chilov, D.; Lahtinen, I.; Kukk, E.; Saksela, O.; Kalkkinen, N.; Alitalo, K. A novel vascular endothelial growth factor, vegf-c, is a ligand for the flt4 (vegfr-3) and kdr (vegfr-2) receptor tyrosine kinases. EMBO J. 1996, 15, 1751. [CrossRef] [PubMed]

23. Achen, M.G.; Jeltsch, M.; Kukk, E.; Makinen, T.; Vitali, A.; Wilks, A.F.; Alitalo, K.; Stacker, S.A. Vascular endothelial growth factor $\mathrm{d}$ (vegf-d) is a ligand for the tyrosine kinases vegf receptor 2 (flk1) and vegf receptor 3 (flt4). Proc. Natl. Acad. Sci. USA 1998, 95, 548-553. [CrossRef]

24. Ghalamkarpour, A.; Morlot, S.; Raas-Rothschild, A.; Utkus, A.; Mulliken, J.B.; Boon, L.M.; Vikkula, M. Hereditary lymphedema type i associated with vegfr3 mutation: The first de novo case and atypical presentations. Clin. Genet. 2006, 70, 330-335. [CrossRef] 
25. Karkkainen, M.J.; Haiko, P.; Sainio, K.; Partanen, J.; Taipale, J.; Petrova, T.V.; Jeltsch, M.; Jackson, D.G.; Talikka, M.; Rauvala, H.; et al. Vascular endothelial growth factor c is required for sprouting of the first lymphatic vessels from embryonic veins. Nat. Immunol. 2004, 5, 74-80. [CrossRef]

26. Pajusola, K.; Aprelikova, O.; Pelicci, G.; Weich, H.; Claesson-Welsh, L.; Alitalo, K. Signalling properties of flt4, a proteolytically processed receptor tyrosine kinase related to two vegf receptors. Oncogene 1994, 9, 3545-3555. [PubMed]

27. Jeltsch, M.; Karpanen, T.; Strandin, T.; Aho, K.; Lankinen, H.; Alitalo, K. Vascular endothelial growth factor (vegf)/vegf-c mosaic molecules reveal specificity determinants and feature novel receptor binding patterns. J. Biol. Chem. 2006, 281, 12187-12195. [CrossRef] [PubMed]

28. Leppanen, V.M.; Tvorogov, D.; Kisko, K.; Prota, A.E.; Jeltsch, M.; Anisimov, A.; Markovic-Mueller, S.; Stuttfeld, E.; Goldie, K.N.; Ballmer-Hofer, K.; et al. Structural and mechanistic insights into vegf receptor 3 ligand binding and activation. Proc. Natl. Acad. Sci. USA 2013, 110, 12960-12965. [CrossRef] [PubMed]

29. Baldwin, M.E.; Halford, M.M.; Roufail, S.; Williams, R.A.; Hibbs, M.L.; Grail, D.; Kubo, H.; Stacker, S.A.; Achen, M.G. Vascular endothelial growth factor $\mathrm{d}$ is dispensable for development of the lymphatic system. Mol. Cell. Biol. 2005, 25, 2441-2449. [CrossRef] [PubMed]

30. Koch, M.; Dettori, D.; Van Nuffelen, A.; Souffreau, J.; Marconcini, L.; Wallays, G.; Moons, L.; Bruyere, F.; Oliviero, S.; Noel, A.; et al. Vegf-d deficiency in mice does not affect embryonic or postnatal lymphangiogenesis but reduces lymphatic metastasis. J. Pathol. 2009, 219, 356-364. [CrossRef]

31. Fournier, E.; Dubreuil, P.; Birnbaum, D.; Borg, J.P. Mutation at tyrosine residue 1337 abrogates ligand-dependent transforming capacity of the flt4 receptor. Oncogene 1995, 11, 921-931. [PubMed]

32. Makinen, T.; Veikkola, T.; Mustjoki, S.; Karpanen, T.; Catimel, B.; Nice, E.C.; Wise, L.; Mercer, A.; Kowalski, H.; Kerjaschki, D.; et al. Isolated lymphatic endothelial cells transduce growth, survival and migratory signals via the vegf-c/d receptor vegfr-3. EMBO J. 2001, 20, 4762-4773. [CrossRef] [PubMed]

33. Salameh, A.; Galvagni, F.; Bardelli, M.; Bussolino, F.; Oliviero, S. Direct recruitment of crk and grb2 to vegfr-3 induces proliferation, migration, and survival of endothelial cells through the activation of erk, akt, and jnk pathways. Blood 2005, 106, 3423-3431. [CrossRef] [PubMed]

34. Eichmann, A.; Makinen, T.; Alitalo, K. Neural guidance molecules regulate vascular remodeling and vessel navigation. Genes Dev. 2005, 19, 1013-1021. [CrossRef] [PubMed]

35. Herzog, Y.; Kalcheim, C.; Kahane, N.; Reshef, R.; Neufeld, G. Differential expression of neuropilin-1 and neuropilin-2 in arteries and veins. Mech. Dev. 2001, 109, 115-119. [CrossRef]

36. Whitaker, G.B.; Limberg, B.J.; Rosenbaum, J.S. Vascular endothelial growth factor receptor-2 and neuropilin-1 form a receptor complex that is responsible for the differential signaling potency of vegf(165) and vegf(121). J. Biol. Chem. 2001, 276, 25520-25531. [CrossRef] [PubMed]

37. Soker, S.; Miao, H.Q.; Nomi, M.; Takashima, S.; Klagsbrun, M. Vegf165 mediates formation of complexes containing vegfr-2 and neuropilin-1 that enhance vegf165-receptor binding. J. Cell. Biochem. 2002, 85, 357-368. [CrossRef]

38. Yuan, L.; Moyon, D.; Pardanaud, L.; Breant, C.; Karkkainen, M.J.; Alitalo, K.; Eichmann, A. Abnormal lymphatic vessel development in neuropilin 2 mutant mice. Development 2002, 129, 4797-4806.

39. Kukk, E.; Lymboussaki, A.; Taira, S.; Kaipainen, A.; Jeltsch, M.; Joukov, V.; Alitalo, K. Vegf-c receptor binding and pattern of expression with vegfr-3 suggests a role in lymphatic vascular development. Development 1996, 122, 3829-3837.

40. Wang, J.; Huang, Y.; Zhang, J.; Xing, B.; Xuan, W.; Wang, H.; Huang, H.; Yang, J.; Tang, J. Nrp-2 in tumor lymphangiogenesis and lymphatic metastasis. Cancer Lett. 2018, 418, 176-184. [CrossRef]

41. Karpanen, T.; Heckman, C.A.; Keskitalo, S.; Jeltsch, M.; Ollila, H.; Neufeld, G.; Tamagnone, L.; Alitalo, K. Functional interaction of vegf-c and vegf-d with neuropilin receptors. FASEB J. 2006, 20, 1462-1472. [CrossRef] [PubMed]

42. Xu, Y.; Yuan, L.; Mak, J.; Pardanaud, L.; Caunt, M.; Kasman, I.; Larrivee, B.; Del Toro, R.; Suchting, S.; Medvinsky, A.; et al. Neuropilin-2 mediates vegf-c-induced lymphatic sprouting together with vegfr3. J. Cell. Biol. 2010, 188, 115-130. [CrossRef]

43. Kaipainen, A.; Korhonen, J.; Mustonen, T.; van Hinsbergh, V.W.; Fang, G.H.; Dumont, D.; Breitman, M.; Alitalo, K. Expression of the fms-like tyrosine kinase 4 gene becomes restricted to lymphatic endothelium during development. Proc. Natl. Acad. Sci. USA 1995, 92, 3566-3570. [CrossRef] 
44. Partanen, T.A.; Arola, J.; Saaristo, A.; Jussila, L.; Ora, A.; Miettinen, M.; Stacker, S.A.; Achen, M.G.; Alitalo, K. Vegf-c and vegf-d expression in neuroendocrine cells and their receptor, vegfr-3, in fenestrated blood vessels in human tissues. FASEB J. 2000, 14, 2087-2096. [CrossRef] [PubMed]

45. Stacker, S.A.; Achen, M.G.; Jussila, L.; Baldwin, M.E.; Alitalo, K. Lymphangiogenesis and cancer metastasis. Nat. Rev. Cancer 2002, 2, 573-583. [CrossRef] [PubMed]

46. Partanen, T.A.; Alitalo, K.; Miettinen, M. Lack of lymphatic vascular specificity of vascular endothelial growth factor receptor 3 in 185 vascular tumors. Cancer 1999, 86, 2406-2412. [CrossRef]

47. Paavonen, K.; Puolakkainen, P.; Jussila, L.; Jahkola, T.; Alitalo, K. Vascular endothelial growth factor receptor-3 in lymphangiogenesis in wound healing. Am. J. Pathol. 2000, 156, 1499-1504. [CrossRef]

48. Valtola, R.; Salven, P.; Heikkila, P.; Taipale, J.; Joensuu, H.; Rehn, M.; Pihlajaniemi, T.; Weich, H.; deWaal, R.; Alitalo, K. Vegfr-3 and its ligand vegf-c are associated with angiogenesis in breast cancer. Am. J. Pathol. 1999, 154, 1381-1390. [CrossRef]

49. Tammela, T.; Zarkada, G.; Wallgard, E.; Murtomaki, A.; Suchting, S.; Wirzenius, M.; Waltari, M.; Hellstrom, M.; Schomber, T.; Peltonen, R.; et al. Blocking vegfr-3 suppresses angiogenic sprouting and vascular network formation. Nature 2008, 454, 656-660. [CrossRef]

50. Le Bras, B.; Barallobre, M.J.; Homman-Ludiye, J.; Ny, A.; Wyns, S.; Tammela, T.; Haiko, P.; Karkkainen, M.J.; Yuan, L.; Muriel, M.P.; et al. Vegf-c is a trophic factor for neural progenitors in the vertebrate embryonic brain. Nat. Neurosci. 2006, 9, 340-348. [CrossRef]

51. Orlandini, M.; Spreafico, A.; Bardelli, M.; Rocchigiani, M.; Salameh, A.; Nucciotti, S.; Capperucci, C.; Frediani, B.; Oliviero, S. Vascular endothelial growth factor-d activates vegfr-3 expressed in osteoblasts inducing their differentiation. J. Biol. Chem. 2006, 281, 17961-17967. [CrossRef]

52. Schmeisser, A.; Christoph, M.; Augstein, A.; Marquetant, R.; Kasper, M.; Braun-Dullaeus, R.C.; Strasser, R.H. Apoptosis of human macrophages by flt-4 signaling: Implications for atherosclerotic plaque pathology. Cardiovasc. Res. 2006, 71, 774-784. [CrossRef]

53. Batsi, O.; Giannopoulou, I.; Nesseris, I.; Valavanis, C.; Gakiopoulou, H.; Patsouris, E.S.; Arapandoni-Dadioti, P.; Lazaris, A.C. Immunohistochemical evaluation of cxcl12-cxcr4 axis and vegfr3 expression in primary urothelial cancer and its recurrence. Anticancer Res. 2014, 34, 3537-3542.

54. Goussia, A.; Simou, N.; Zagouri, F.; Manousou, K.; Lazaridis, G.; Gogas, H.; Koutras, A.; Sotiropoulou, M.; Pentheroudakis, G.; Bafaloukos, D.; et al. Associations of angiogenesis-related proteins with specific prognostic factors, breast cancer subtypes and survival outcome in early-stage breast cancer patients. A hellenic cooperative oncology group (hecog) trial. PLoS ONE 2018, 13, e0200302. [CrossRef] [PubMed]

55. Varney, M.L.; Singh, R.K. Vegf-c-vegfr3/flt4 axis regulates mammary tumor growth and metastasis in an autocrine manner. Am. J. Cancer Res. 2015, 5, 616-628. [PubMed]

56. Eroglu, A.; Ersoz, C.; Karasoy, D.; Sak, S. Vascular endothelial growth factor (vegf)-c, vegf-d, vegfr-3 and d2-40 expressions in primary breast cancer: Association with lymph node metastasis. Adv. Clin. Exp. Med. 2017, 26, 245-249.

57. Takizawa, H.; Kondo, K.; Fujino, H.; Kenzaki, K.; Miyoshi, T.; Sakiyama, S.; Tangoku, A. The balance of vegf-c and vegfr-3 mrna is a predictor of lymph node metastasis in non-small cell lung cancer. Br. J. Cancer 2006, 95, 75-79. [CrossRef]

58. Li, Y.; Weng, Y.; Zhong, L.; Chong, H.; Chen, S.; Sun, Y.; Li, W.; Shi, Q. Vegfr3 inhibition chemosensitizes lung adenocarcinoma a549 cells in the tumor-associated macrophage microenvironment through upregulation of p53 and pten. Oncol. Rep. 2017, 38, 2761-2773. [CrossRef]

59. Lim, J.J.; Yang, K.; Taylor-Harding, B.; Wiedemeyer, W.R.; Buckanovich, R.J. Vegfr3 inhibition chemosensitizes ovarian cancer stemlike cells through down-regulation of brca1 and brca2. Neoplasia 2014, 16, 343-353.e2. [CrossRef]

60. Decio, A.; Taraboletti, G.; Patton, V.; Alzani, R.; Perego, P.; Fruscio, R.; Jurgensmeier, J.M.; Giavazzi, R.; Belotti, D. Vascular endothelial growth factor c promotes ovarian carcinoma progression through paracrine and autocrine mechanisms. Am. J. Pathol. 2014, 184, 1050-1061. [CrossRef]

61. Virman, J.; Bono, P.; Luukkaala, T.; Sunela, K.; Kujala, P.; Kellokumpu-Lehtinen, P.L. Vegfr3 and cd31 as prognostic factors in renal cell cancer. Anticancer Res. 2015, 35, 921-927. [PubMed]

62. Bierer, S.; Herrmann, E.; Kopke, T.; Neumann, J.; Eltze, E.; Hertle, L.; Wulfing, C. Lymphangiogenesis in kidney cancer: Expression of vegf-c, vegf-d and vegfr-3 in clear cell and papillary renal cell carcinoma. Oncol. Rep. 2008, 20, 721-725. [CrossRef] [PubMed] 
63. Zhang, Y.H.; Diao, L.; Yang, Q.; Duo, J.; Liu, Y.X.; Liu, S.X.; Yao, X. expression of vegfr-2 and vegfr-3 in papillary renal cell carcinoma and their relationship with prognosis. Zhonghua Zhong Liu Za Zhi 2010, 32, 752-756. [PubMed]

64. Wang, J.; Taylor, A.; Showeil, R.; Trivedi, P.; Horimoto, Y.; Bagwan, I.; Ewington, L.; Lam, E.W.; El-Bahrawy, M.A. Expression profiling and significance of vegf-a, vegfr2, vegfr3 and related proteins in endometrial carcinoma. Cytokine 2014, 68, 94-100. [CrossRef]

65. Xin, X.; Zeng, X.; Feng, D.; Hua, T.; Liu, S.; Chi, S.; Hu, Q.; Wang, H. The suppressive role of calcium sensing receptor in endometrial cancer. Sci. Rep. 2018, 8, 1076. [CrossRef] [PubMed]

66. Zhu, G.; Huang, Q.; Zheng, W.; Huang, Y.; Hua, J.; Yang, S.; Zhuang, J.; Wang, J.; Chang, J.; Xu, J.; et al. Lps upregulated vegfr-3 expression promote migration and invasion in colorectal cancer via a mechanism of increased nf-kappab binding to the promoter of vegfr-3. Cell. Physiol. Biochem. 2016, 39, 1665-1678. [CrossRef] [PubMed]

67. Paiva, T.F., Jr.; de Jesus, V.H.; Marques, R.A.; da Costa, A.A.; de Macedo, M.P.; Peresi, P.M.; Damascena, A.; Rossi, B.M.; Begnami, M.D.; de Lima, V.C. Angiogenesis-related protein expression in bevacizumab-treated metastatic colorectal cancer: Notch1 detrimental to overall survival. BMC Cancer 2015, 15, 643. [CrossRef]

68. Hong, K.D.; Lee, Y.; Kim, B.H.; Lee, S.I.; Moon, H.Y. Expression of gli1 correlates with expression of lymphangiogenesis proteins, vascular endothelial growth factor $\mathrm{c}$ and vascular endothelial growth factor receptor 3, in colorectal cancer. Am. Surg. 2013, 79, 198-204.

69. Yu, J.W.; Wu, S.H.; Lu, R.Q.; Wu, J.G.; Ni, X.C.; Zhou, G.C.; Jiang, H.G.; Zheng, L.H.; Li, X.Q.; Du, G.Y.; et al. Expression and significances of contactin-1 in human gastric cancer. Gastroenterol. Res. Pract. 2013, 2013, 210205. [CrossRef]

70. Dai, X.; Liu, D.; Liu, M.; Zhang, X.; Wang, W.; Jin, F.; Qian, Y.; Wang, X.; Zhao, J.; Wu, Y.; et al. Anti-metastatic efficacy of traditional chinese medicine $(\mathrm{tcm})$ ginsenoside conjugated to a vefgr-3 antibody on human gastric cancer in an orthotopic mouse model. Anticancer Res. 2017, 37, 979-986.

71. Zhang, H.; Qi, F.; Cao, Y.; Zu, X.; Chen, M.; Li, Z.; Qi, L. 5-aza-2'-deoxycytidine enhances maspin expression and inhibits proliferation, migration, and invasion of the bladder cancer $\mathrm{t} 24$ cell line. Cancer Biother. Radiopharm. 2013, 28, 343-350. [CrossRef] [PubMed]

72. Al-Shareef, H.; Hiraoka, S.I.; Tanaka, N.; Shogen, Y.; Lee, A.D.; Bakhshishayan, S.; Kogo, M. Use of nrp1, a novel biomarker, along with vegf-c, vegfr-3, ccr7 and sema3e, to predict lymph node metastasis in squamous cell carcinoma of the tongue. Oncol. Rep. 2016, 36, 2444-2454. [CrossRef] [PubMed]

73. Misawa, Y.; Misawa, K.; Kawasaki, H.; Imai, A.; Mochizuki, D.; Ishikawa, R.; Endo, S.; Mima, M.; Kanazawa, T.; Iwashita, T.; et al. Evaluation of epigenetic inactivation of vascular endothelial growth factor receptors in head and neck squamous cell carcinoma. Tumour Biol. 2017, 39, 1010428317711657. [CrossRef] [PubMed]

74. Maurer, J.; Schopp, M.; Thurau, K.; Haier, J.; Kohler, G.; Hummel, R. Immunohistochemical analysis on potential new molecular targets for esophageal cancer. Dis. Esophagus 2014, 27, 93-100. [CrossRef] [PubMed]

75. Gockel, I.; Moehler, M.; Frerichs, K.; Drescher, D.; Trinh, T.T.; Duenschede, F.; Borschitz, T.; Schimanski, K.; Biesterfeld, S.; Herzer, K.; et al. Co-expression of receptor tyrosine kinases in esophageal adenocarcinoma and squamous cell cancer. Oncol. Rep. 2008, 20, 845-850.

76. Van Trappen, P.O.; Steele, D.; Lowe, D.G.; Baithun, S.; Beasley, N.; Thiele, W.; Weich, H.; Krishnan, J.; Shepherd, J.H.; Pepper, M.S.; et al. Expression of vascular endothelial growth factor (vegf)-c and vegf-d, and their receptor vegfr-3, during different stages of cervical carcinogenesis. J. Pathol. 2003, 201, 544-554. [CrossRef]

77. Shi, X.; Chen, G.; Xing, H.; Weng, D.; Bai, X.; Ma, D. Vegf-c, vegfr-3, and cox-2 enhances growth and metastasis of human cervical carcinoma cell lines in vitro. Oncol. Rep. 2007, 18, 241-247. [CrossRef]

78. Kaushal, V.; Mukunyadzi, P.; Dennis, R.A.; Siegel, E.R.; Johnson, D.E.; Kohli, M. Stage-specific characterization of the vascular endothelial growth factor axis in prostate cancer: Expression of lymphangiogenic markers is associated with advanced-stage disease. Clin. Cancer Res. 2005, 11, 584-593.

79. Yang, Z.S.; Xu, Y.F.; Huang, F.F.; Ding, G.F. Associations of nm23h1, vegf-c, and vegf-3 receptor in human prostate cancer. Molecules 2014, 19, 6851-6862. [CrossRef]

80. Rodriguez-Antona, C.; Munoz-Repeto, I.; Inglada-Perez, L.; de Cubas, A.A.; Mancikova, V.; Canamero, M.; Maliszewska, A.; Gomez, A.; Leton, R.; Leandro-Garcia, L.J.; et al. Influence of ret mutations on the expression of tyrosine kinases in medullary thyroid carcinoma. Endocr. Relat. Cancer 2013, 20, 611-619. [CrossRef] 
81. Mancikova, V.; Inglada-Perez, L.; Curras-Freixes, M.; de Cubas, A.A.; Gomez, A.; Leton, R.; Kersten, I.; Leandro-Garcia, L.J.; Comino-Mendez, I.; Apellaniz-Ruiz, M.; et al. Vegf, vegfr3, and pdgfrb protein expression is influenced by ras mutations in medullary thyroid carcinoma. Thyroid 2014, 24, 1251-1255. [CrossRef] [PubMed]

82. Kurenova, E.; Liao, J.; He, D.H.; Hunt, D.; Yemma, M.; Bshara, W.; Seshadri, M.; Cance, W.G. The fak scaffold inhibitor c4 disrupts fak-vegfr-3 signaling and inhibits pancreatic cancer growth. Oncotarget 2013, 4, 1632-1646. [CrossRef]

83. Gogate, P.N.; Kurenova, E.V.; Ethirajan, M.; Liao, J.; Yemma, M.; Sen, A.; Pandey, R.K.; Cance, W.G. Targeting the c-terminal focal adhesion kinase scaffold in pancreatic cancer. Cancer Lett. 2014, 353, 281-289. [CrossRef] [PubMed]

84. Beierle, E.A.; Dai, W.; Langham, M.R., Jr.; Copeland, E.M., 3rd; Chen, M.K. Expression of vegf receptors in cocultured neuroblastoma cells. J. Surg. Res. 2004, 119, 56-65. [CrossRef] [PubMed]

85. Stewart, J.E.; Ma, X.; Megison, M.; Nabers, H.; Cance, W.G.; Kurenova, E.V.; Beierle, E.A. Inhibition of fak and vegfr-3 binding decreases tumorigenicity in neuroblastoma. Mol. Carcinog. 2015, 54, 9-23. [CrossRef] [PubMed]

86. Mehnert, J.M.; McCarthy, M.M.; Jilaveanu, L.; Flaherty, K.T.; Aziz, S.; Camp, R.L.; Rimm, D.L.; Kluger, H.M. Quantitative expression of vegf, vegf-r1, vegf-r2, and vegf-r3 in melanoma tissue microarrays. Hum. Pathol. 2010, 41, 375-384. [CrossRef] [PubMed]

87. Kurenova, E.; Ucar, D.; Liao, J.; Yemma, M.; Gogate, P.; Bshara, W.; Sunar, U.; Seshadri, M.; Hochwald, S.N.; Cance, W.G. A fak scaffold inhibitor disrupts fak and vegfr-3 signaling and blocks melanoma growth by targeting both tumor and endothelial cells. Cell Cycle 2014, 13, 2542-2553. [CrossRef]

88. Jenny, B.; Harrison, J.A.; Baetens, D.; Tille, J.C.; Burkhardt, K.; Mottaz, H.; Kiss, J.Z.; Dietrich, P.Y.; De Tribolet, N.; Pizzolato, G.P.; et al. Expression and localization of vegf-c and vegfr-3 in glioblastomas and haemangioblastomas. J. Pathol. 2006, 209, 34-43. [CrossRef] [PubMed]

89. Yoshimoto, K.; Ma, X.; Guan, Y.; Mizoguchi, M.; Nakamizo, A.; Amano, T.; Hata, N.; Kuga, D.; Sasaki, T. Expression of stem cell marker and receptor kinase genes in glioblastoma tissue quantified by real-time rt-pcr. Brain Tumor Pathol. 2011, 28, 291-296. [CrossRef] [PubMed]

90. Park, H.R.; Min, K.; Kim, H.S.; Jung, W.W.; Park, Y.K. Expression of vascular endothelial growth factor-c and its receptor in osteosarcomas. Pathol. Res. Pract. 2008, 204, 575-582. [CrossRef]

91. Wang, Z.; Chen, Y.; Li, X.; Xu, L.; Ma, W.; Chang, L.; Ju, F. Expression of vegf-c/vegfr-3 in human laryngeal squamous cell carcinomas and its significance for lymphatic metastasis. Asian Pac. J. Cancer Prev. 2012, 13, 27-31. [CrossRef]

92. Yeh, Y.W.; Cheng, C.C.; Yang, S.T.; Tseng, C.F.; Chang, T.Y.; Tsai, S.Y.; Fu, E.; Chiang, C.P.; Liao, L.C.; Tsai, P.W.; et al. Targeting the vegf-c/vegfr3 axis suppresses slug-mediated cancer metastasis and stemness via inhibition of kras/yap1 signaling. Oncotarget 2017, 8, 5603-5618. [CrossRef]

93. Lee, J.Y.; Park, S.; Kim, D.C.; Yoon, J.H.; Shin, S.H.; Min, W.S.; Kim, H.J. A vegfr-3 antagonist increases ifn-gamma expression on low functioning nk cells in acute myeloid leukemia. J. Clin. Immunol. 2013, 33, 826-837. [CrossRef]

94. Baluk, P.; Fuxe, J.; Hashizume, H.; Romano, T.; Lashnits, E.; Butz, S.; Vestweber, D.; Corada, M.; Molendini, C.; Dejana, E.; et al. Functionally specialized junctions between endothelial cells of lymphatic vessels. J. Exp. Med. 2007, 204, 2349-2362. [CrossRef]

95. Schulte-Merker, S.; Sabine, A.; Petrova, T.V. Lymphatic vascular morphogenesis in development, physiology, and disease. J. Cell. Biol. 2011, 193, 607-618. [CrossRef]

96. Witte, M.H.; Bernas, M.J.; Martin, C.P.; Witte, C.L. Lymphangiogenesis and lymphangiodysplasia: From molecular to clinical lymphology. Microsc. Res. Tech. 2001, 55, 122-145. [CrossRef]

97. Tammela, T.; Alitalo, K. Lymphangiogenesis: Molecular mechanisms and future promise. Cell 2010, 140, 460-476. [CrossRef]

98. Karkkainen, M.J.; Ferrell, R.E.; Lawrence, E.C.; Kimak, M.A.; Levinson, K.L.; McTigue, M.A.; Alitalo, K.; Finegold, D.N. Missense mutations interfere with vegfr-3 signalling in primary lymphoedema. Nat. Genet. 2000, 25, 153-159. [CrossRef]

99. Karkkainen, M.J.; Saaristo, A.; Jussila, L.; Karila, K.A.; Lawrence, E.C.; Pajusola, K.; Bueler, H.; Eichmann, A.; Kauppinen, R.; Kettunen, M.I.; et al. A model for gene therapy of human hereditary lymphedema. Proc. Natl. Acad. Sci. USA 2001, 98, 12677-12682. [CrossRef] 
100. Dumont, D.J.; Jussila, L.; Taipale, J.; Lymboussaki, A.; Mustonen, T.; Pajusola, K.; Breitman, M.; Alitalo, K. Cardiovascular failure in mouse embryos deficient in vegf receptor-3. Science 1998, 282, 946-949. [CrossRef]

101. Hagerling, R.; Pollmann, C.; Andreas, M.; Schmidt, C.; Nurmi, H.; Adams, R.H.; Alitalo, K.; Andresen, V.; Schulte-Merker, S.; Kiefer, F. A novel multistep mechanism for initial lymphangiogenesis in mouse embryos based on ultramicroscopy. EMBO J. 2013, 32, 629-644. [CrossRef]

102. Jeltsch, M.; Jha, S.K.; Tvorogov, D.; Anisimov, A.; Leppanen, V.M.; Holopainen, T.; Kivela, R.; Ortega, S.; Karpanen, T.; Alitalo, K. Ccbe1 enhances lymphangiogenesis via a disintegrin and metalloprotease with thrombospondin motifs-3-mediated vascular endothelial growth factor-c activation. Circulation 2014, 129, 1962-1971. [CrossRef]

103. Roukens, M.G.; Peterson-Maduro, J.; Padberg, Y.; Jeltsch, M.; Leppanen, V.M.; Bos, F.L.; Alitalo, K.; Schulte-Merker, S.; Schulte, D. Functional dissection of the ccbe1 protein: A crucial requirement for the collagen repeat domain. Circ. Res. 2015, 116, 1660-1669. [CrossRef]

104. Jeltsch, M.; Kaipainen, A.; Joukov, V.; Meng, X.; Lakso, M.; Rauvala, H.; Swartz, M.; Fukumura, D.; Jain, R.K.; Alitalo, K. Hyperplasia of lymphatic vessels in vegf-c transgenic mice. Science 1997, 276, 1423-1425. [CrossRef]

105. Kurebayashi, J.; Otsuki, T.; Kunisue, H.; Mikami, Y.; Tanaka, K.; Yamamoto, S.; Sonoo, H. Expression of vascular endothelial growth factor (vegf) family members in breast cancer. Jpn. J. Cancer Res. 1999, 90, 977-981. [CrossRef]

106. Salven, P.; Lymboussaki, A.; Heikkila, P.; Jaaskela-Saari, H.; Enholm, B.; Aase, K.; von Euler, G.; Eriksson, U.; Alitalo, K.; Joensuu, H. Vascular endothelial growth factors vegf-b and vegf-c are expressed in human tumors. Am. J. Pathol. 1998, 153, 103-108. [CrossRef]

107. Akagi, K.; Ikeda, Y.; Miyazaki, M.; Abe, T.; Kinoshita, J.; Maehara, Y.; Sugimachi, K. Vascular endothelial growth factor-c (vegf-c) expression in human colorectal cancer tissues. Br. J. Cancer 2000, 83, 887-891. [CrossRef]

108. Niki, T.; Iba, S.; Tokunou, M.; Yamada, T.; Matsuno, Y.; Hirohashi, S. Expression of vascular endothelial growth factors $\mathrm{a}, \mathrm{b}, \mathrm{c}$, and $\mathrm{d}$ and their relationships to lymph node status in lung adenocarcinoma. Clin. Cancer Res. 2000, 6, 2431-2439.

109. Shushanov, S.; Bronstein, M.; Adelaide, J.; Jussila, L.; Tchipysheva, T.; Jacquemier, J.; Stavrovskaya, A.; Birnbaum, D.; Karamysheva, A. Vegfc and vegfr3 expression in human thyroid pathologies. Int. J. Cancer 2000, 86, 47-52. [CrossRef]

110. Yonemura, Y.; Endo, Y.; Fujita, H.; Fushida, S.; Ninomiya, I.; Bandou, E.; Taniguchi, K.; Miwa, K.; Ohoyama, S.; Sugiyama, K.; et al. Role of vascular endothelial growth factor c expression in the development of lymph node metastasis in gastric cancer. Clin. Cancer Res. 1999, 5, 1823-1829.

111. Ohta, Y.; Shridhar, V.; Bright, R.K.; Kalemkerian, G.P.; Du, W.; Carbone, M.; Watanabe, Y.; Pass, H.I. Vegf and vegf type c play an important role in angiogenesis and lymphangiogenesis in human malignant mesothelioma tumours. Br. J. Cancer 1999, 81, 54-61. [CrossRef]

112. Eggert, A.; Ikegaki, N.; Kwiatkowski, J.; Zhao, H.; Brodeur, G.M.; Himelstein, B.P. High-level expression of angiogenic factors is associated with advanced tumor stage in human neuroblastomas. Clin. Cancer Res. 2000, 6, 1900-1908.

113. Lohela, M.; Bry, M.; Tammela, T.; Alitalo, K. Vegfs and receptors involved in angiogenesis versus lymphangiogenesis. Curr. Opin. Cell Biol. 2009, 21, 154-165. [CrossRef]

114. Skobe, M.; Hawighorst, T.; Jackson, D.G.; Prevo, R.; Janes, L.; Velasco, P.; Riccardi, L.; Alitalo, K.; Claffey, K.; Detmar, M. Induction of tumor lymphangiogenesis by vegf-c promotes breast cancer metastasis. Nat. Med. 2001, 7, 192-198. [CrossRef]

115. Karpanen, T.; Alitalo, K. Lymphatic vessels as targets of tumor therapy? J. Exp. Med. 2001, 194, F37-F42. [CrossRef]

116. Mattila, M.M.; Ruohola, J.K.; Karpanen, T.; Jackson, D.G.; Alitalo, K.; Harkonen, P.L. Vegf-c induced lymphangiogenesis is associated with lymph node metastasis in orthotopic mcf-7 tumors. Int. J. Cancer 2002, 98, 946-951. [CrossRef]

117. Makinen, T.; Jussila, L.; Veikkola, T.; Karpanen, T.; Kettunen, M.I.; Pulkkanen, K.J.; Kauppinen, R.; Jackson, D.G.; Kubo, H.; Nishikawa, S.; et al. Inhibition of lymphangiogenesis with resulting lymphedema in transgenic mice expressing soluble vegf receptor-3. Nat. Med. 2001, 7, 199-205. [CrossRef] 
118. Friedlaender, M.H.; Baer, H. Immunologic tolerance: Role of the regional lymph node. Science 1972, 176, 312-314. [CrossRef]

119. Friedlaender, M.H.; Chisari, F.V.; Baer, H. The role of the inflammatory response of skin and lymph nodes in the induction of sensitization to simple chemicals. J. Immunol. 1973, 111, 164-170.

120. D'Alessio, S.; Correale, C.; Tacconi, C.; Gandelli, A.; Pietrogrande, G.; Vetrano, S.; Genua, M.; Arena, V.; Spinelli, A.; Peyrin-Biroulet, L.; et al. Vegf-c-dependent stimulation of lymphatic function ameliorates experimental inflammatory bowel disease. J. Clin. Investig. 2014, 124, 3863-3878. [CrossRef]

121. Huggenberger, R.; Ullmann, S.; Proulx, S.T.; Pytowski, B.; Alitalo, K.; Detmar, M. Stimulation of lymphangiogenesis via vegfr-3 inhibits chronic skin inflammation. J. Exp. Med. 2010, 207, 2255-2269. [CrossRef]

122. Yao, L.C.; Baluk, P.; Feng, J.; McDonald, D.M. Steroid-resistant lymphatic remodeling in chronically inflamed mouse airways. Am. J. Pathol. 2010, 176, 1525-1541. [CrossRef]

123. Fiedler, E.; Helmbold, P.; Marsch, W.C. Increased vessel density in psoriasis: Involvement of lymphatic vessels in the papillary dermis. Br. J. Dermatol. 2008, 159, 258-261. [CrossRef]

124. Hamrah, P.; Chen, L.; Zhang, Q.; Dana, M.R. Novel expression of vascular endothelial growth factor receptor (vegfr)-3 and vegf-c on corneal dendritic cells. Am. J. Pathol. 2003, 163, 57-68. [CrossRef]

125. Fernandez Pujol, B.; Lucibello, F.C.; Zuzarte, M.; Lutjens, P.; Muller, R.; Havemann, K. Dendritic cells derived from peripheral monocytes express endothelial markers and in the presence of angiogenic growth factors differentiate into endothelial-like cells. Eur J. Cell. Biol. 2001, 80, 99-110. [CrossRef]

126. Schoppmann, S.F.; Birner, P.; Stockl, J.; Kalt, R.; Ullrich, R.; Caucig, C.; Kriehuber, E.; Nagy, K.; Alitalo, K.; Kerjaschki, D. Tumor-associated macrophages express lymphatic endothelial growth factors and are related to peritumoral lymphangiogenesis. Am. J. Pathol. 2002, 161, 947-956. [CrossRef]

127. Su, J.L.; Yen, C.J.; Chen, P.S.; Chuang, S.E.; Hong, C.C.; Kuo, I.H.; Chen, H.Y.; Hung, M.C.; Kuo, M.L. The role of the vegf-c/vegfr-3 axis in cancer progression. Br. J. Cancer 2007, 96, 541-545. [CrossRef]

128. Zhang, Y.; Lu, Y.; Ma, L.; Cao, X.; Xiao, J.; Chen, J.; Jiao, S.; Gao, Y.; Liu, C.; Duan, Z.; et al. Activation of vascular endothelial growth factor receptor-3 in macrophages restrains tlr4-nf-kappab signaling and protects against endotoxin shock. Immunity 2014, 40, 501-514. [CrossRef]

129. Harrell, M.I.; Iritani, B.M.; Ruddell, A. Tumor-induced sentinel lymph node lymphangiogenesis and increased lymph flow precede melanoma metastasis. Am. J. Pathol. 2007, 170, 774-786. [CrossRef]

130. Lund, A.W.; Duraes, F.V.; Hirosue, S.; Raghavan, V.R.; Nembrini, C.; Thomas, S.N.; Issa, A.; Hugues, S.; Swartz, M.A. Vegf-c promotes immune tolerance in b16 melanomas and cross-presentation of tumor antigen by lymph node lymphatics. Cell Rep. 2012, 1, 191-199. [CrossRef]

131. Swartz, M.A.; Lund, A.W. Lymphatic and interstitial flow in the tumour microenvironment: Linking mechanobiology with immunity. Nat. Rev. Cancer 2012, 12, 210-219. [CrossRef]

132. Kerjaschki, D.; Regele, H.M.; Moosberger, I.; Nagy-Bojarski, K.; Watschinger, B.; Soleiman, A.; Birner, P.; Krieger, S.; Hovorka, A.; Silberhumer, G.; et al. Lymphatic neoangiogenesis in human kidney transplants is associated with immunologically active lymphocytic infiltrates. J. Am. Soc. Nephrol. 2004, 15, 603-612. [CrossRef]

133. Ling, S.; Qi, C.; Li, W.; Xu, J.; Kuang, W. Crucial role of corneal lymphangiogenesis for allograft rejection in alkali-burned cornea bed. Clin. Exp. Ophthalmol. 2009, 37, 874-883. [CrossRef]

134. Zheng, W.; Aspelund, A.; Alitalo, K. Lymphangiogenic factors, mechanisms, and applications. J. Clin. Investig. 2014, 124, 878-887. [CrossRef]

135. Pasquali, S.; van der Ploeg, A.P.; Mocellin, S.; Stretch, J.R.; Thompson, J.F.; Scolyer, R.A. Lymphatic biomarkers in primary melanomas as predictors of regional lymph node metastasis and patient outcomes. Pigment Cell Melanoma Res. 2013, 26, 326-337. [CrossRef]

136. Bhargava, P.; Robinson, M.O. Development of second-generation vegfr tyrosine kinase inhibitors: Current status. Curr. Oncol. Rep. 2011, 13, 103-111. [CrossRef]

137. Albiges, L.; Gizzi, M.; Carton, E.; Escudier, B. Axitinib in metastatic renal cell carcinoma. Expert Rev. Anticancer Ther. 2015, 15, 499-507. [CrossRef]

138. Escudier, B.; Eisen, T.; Stadler, W.M.; Szczylik, C.; Oudard, S.; Siebels, M.; Negrier, S.; Chevreau, C.; Solska, E.; Desai, A.A.; et al. Sorafenib in advanced clear-cell renal-cell carcinoma. N. Engl. J. Med. 2007, 356, 125-134. [CrossRef]

139. Ellis, L.M.; Hicklin, D.J. Vegf-targeted therapy: Mechanisms of anti-tumour activity. Nat. Rev. Cancer 2008, 8, 579-591. [CrossRef] 
140. Motzer, R.J.; Hutson, T.E.; Tomczak, P.; Michaelson, M.D.; Bukowski, R.M.; Rixe, O.; Oudard, S.; Negrier, S.; Szczylik, C.; Kim, S.T.; et al. Sunitinib versus interferon alfa in metastatic renal-cell carcinoma. N. Engl. J. Med. 2007, 356, 115-124. [CrossRef]

141. Sternberg, C.N.; Davis, I.D.; Mardiak, J.; Szczylik, C.; Lee, E.; Wagstaff, J.; Barrios, C.H.; Salman, P.; Gladkov, O.A.; Kavina, A.; et al. Pazopanib in locally advanced or metastatic renal cell carcinoma: Results of a randomized phase iii trial. J. Clin. Oncol. 2010, 28, 1061-1068. [CrossRef]

142. Heckman, C.A.; Holopainen, T.; Wirzenius, M.; Keskitalo, S.; Jeltsch, M.; Yla-Herttuala, S.; Wedge, S.R.; Jurgensmeier, J.M.; Alitalo, K. The tyrosine kinase inhibitor cediranib blocks ligand-induced vascular endothelial growth factor receptor-3 activity and lymphangiogenesis. Cancer Res. 2008, 68, 4754-4762. [CrossRef]

143. Stark, D.P.; Cook, A.; Brown, J.M.; Brundage, M.D.; Embleton, A.C.; Kaplan, R.S.; Raja, F.A.; Swart, A.M.W.; Velikova, G.; Qian, W.; et al. Quality of life with cediranib in relapsed ovarian cancer: The icon6 phase 3 randomized clinical trial. Cancer 2017, 123, 2752-2761. [CrossRef]

144. Kudo, M.; Han, G.; Finn, R.S.; Poon, R.T.; Blanc, J.F.; Yan, L.; Yang, J.; Lu, L.; Tak, W.Y.; Yu, X.; et al. Brivanib as adjuvant therapy to transarterial chemoembolization in patients with hepatocellular carcinoma: A randomized phase iii trial. Hepatology 2014, 60, 1697-1707. [CrossRef]

145. Yoh, K.; Seto, T.; Satouchi, M.; Nishio, M.; Yamamoto, N.; Murakami, H.; Nogami, N.; Matsumoto, S.; Kohno, T.; Tsuta, K.; et al. Vandetanib in patients with previously treated ret-rearranged advanced non-small-cell lung cancer (luret): An open-label, multicentre phase 2 trial. Lancet Respir. Med. 2017, 5, 42-50. [CrossRef]

146. Lee, S.H.; Lee, J.K.; Ahn, M.J.; Kim, D.W.; Sun, J.M.; Keam, B.; Kim, T.M.; Heo, D.S.; Ahn, J.S.; Choi, Y.L.; et al. Vandetanib in pretreated patients with advanced non-small cell lung cancer-harboring ret rearrangement: A phase ii clinical trial. Ann. Oncol. 2017, 28, 292-297.

147. Kubota, K.; Yoshioka, H.; Oshita, F.; Hida, T.; Yoh, K.; Hayashi, H.; Kato, T.; Kaneda, H.; Yamada, K.; Tanaka, H.; et al. Phase iii, randomized, placebo-controlled, double-blind trial of motesanib (amg-706) in combination with paclitaxel and carboplatin in east asian patients with advanced nonsquamous non-small-cell lung cancer. J. Clin. Oncol. 2017, 35, 3662-3670. [CrossRef]

148. Alam, A.; Blanc, I.; Gueguen-Dorbes, G.; Duclos, O.; Bonnin, J.; Barron, P.; Laplace, M.C.; Morin, G.; Gaujarengues, F.; Dol, F.; et al. Sar131675, a potent and selective vegfr-3-tk inhibitor with antilymphangiogenic, antitumoral, and antimetastatic activities. Mol. Cancer Ther. 2012, 11, 1637-1649. [CrossRef]

149. Hwang, S.D.; Song, J.H.; Kim, Y.; Lim, J.H.; Kim, M.Y.; Kim, E.N.; Hong, Y.A.; Chung, S.; Choi, B.S.; Kim, Y.S.; et al. Inhibition of lymphatic proliferation by the selective vegfr-3 inhibitor sar131675 ameliorates diabetic nephropathy in $\mathrm{db} / \mathrm{db}$ mice. Cell Death Dis. 2019, 10, 219. [CrossRef]

150. Hurwitz, H.; Fehrenbacher, L.; Novotny, W.; Cartwright, T.; Hainsworth, J.; Heim, W.; Berlin, J.; Baron, A.; Griffing, S.; Holmgren, E.; et al. Bevacizumab plus irinotecan, fluorouracil, and leucovorin for metastatic colorectal cancer. N. Engl. J. Med. 2004, 350, 2335-2342. [CrossRef]

151. Miller, K.; Wang, M.; Gralow, J.; Dickler, M.; Cobleigh, M.; Perez, E.A.; Shenkier, T.; Cella, D.; Davidson, N.E. Paclitaxel plus bevacizumab versus paclitaxel alone for metastatic breast cancer. N. Engl. J. Med. 2007, 357, 2666-2676. [CrossRef] [PubMed]

152. Sandler, A.; Gray, R.; Perry, M.C.; Brahmer, J.; Schiller, J.H.; Dowlati, A.; Lilenbaum, R.; Johnson, D.H. Paclitaxel-carboplatin alone or with bevacizumab for non-small-cell lung cancer. N. Engl. J. Med. 2006, 355, 2542-2550. [CrossRef]

153. Saif, M.W.; Knost, J.A.; Chiorean, E.G.; Kambhampati, S.R.; Yu, D.; Pytowski, B.; Qin, A.; Kauh, J.S.; O'Neil, B.H. Phase 1 study of the anti-vascular endothelial growth factor receptor 3 monoclonal antibody ly3022856/imc-3c5 in patients with advanced and refractory solid tumors and advanced colorectal cancer. Cancer Chemother. Pharmacol. 2016, 78, 815-824. [CrossRef] [PubMed]

154. Dieterich, L.C.; Detmar, M. Tumor lymphangiogenesis and new drug development. Adv. Drug Deliv. Rev. 2016, 99, 148-160. [CrossRef] [PubMed]

155. Jimenez, X.; Lu, D.; Brennan, L.; Persaud, K.; Liu, M.; Miao, H.; Witte, L.; Zhu, Z. A recombinant, fully human, bispecific antibody neutralizes the biological activities mediated by both vascular endothelial growth factor receptors 2 and 3. Mol. Cancer Ther. 2005, 4, 427-434.

156. Lin, J.; Lalani, A.S.; Harding, T.C.; Gonzalez, M.; Wu, W.W.; Luan, B.; Tu, G.H.; Koprivnikar, K.; VanRoey, M.J.; $\mathrm{He}$, Y.; et al. Inhibition of lymphogenous metastasis using adeno-associated virus-mediated gene transfer of a soluble vegfr-3 decoy receptor. Cancer Res. 2005, 65, 6901-6909. [CrossRef] [PubMed] 
157. Rinderknecht, M.; Villa, A.; Ballmer-Hofer, K.; Neri, D.; Detmar, M. Phage-derived fully human monoclonal antibody fragments to human vascular endothelial growth factor-c block its interaction with vegf receptor-2 and 3. PLoS ONE 2010, 5, e11941. [CrossRef] [PubMed]

158. Zhang, D.; Li, B.; Shi, J.; Zhao, L.; Zhang, X.; Wang, C.; Hou, S.; Qian, W.; Kou, G.; Wang, H.; et al. Suppression of tumor growth and metastasis by simultaneously blocking vascular endothelial growth factor (vegf)-a and vegf-c with a receptor-immunoglobulin fusion protein. Cancer Res. 2010, 70, 2495-2503. [CrossRef]

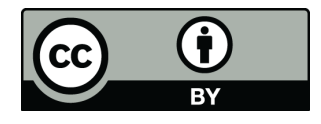

(C) 2019 by the authors. Licensee MDPI, Basel, Switzerland. This article is an open access article distributed under the terms and conditions of the Creative Commons Attribution (CC BY) license (http:/ / creativecommons.org/licenses/by/4.0/). 